\title{
Iodonium ylides in organic synthesis
}

\author{
Mekhman S. Yusubov, ${ }^{*, a}$ Akira Yoshimura, ${ }^{\text {b }}$ and Viktor V. Zhdankin*,a,b \\ ${ }^{a}$ Tomsk Polytechnic University, 634050 Tomsk, Russia \\ ${ }^{b}$ Department of Chemistry and Biochemistry, University of Minnesota Duluth, \\ Duluth, Minnesota, 55812, USA \\ E-mail:vzhdanki@d.umn.edu; yusubov@mail.ru
}

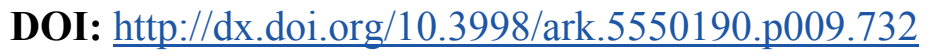

\begin{abstract}
This review summarizes the chemistry of iodonium ylides with emphasis on their synthetic applications. The preparation, structure and chemistry of iodonium ylides of different structural types are overviewed. Iodonium ylides have found synthetic application as efficient carbene precursors, especially useful as reagents for cyclopropanation of alkenes and preparation of heterocyclic compounds. Recently iodonium ylides have been utilized as efficient reagents in the thiotrifluoromethylation and nucleophilic fluorination reactions.
\end{abstract}

Keywords: Hypervalent iodine, iodonium ylides, carbenes, carbenoids, thiotrifluoromethylation

\section{Table of Contents}

1. Introduction

2. Preparation and Properties of Iodonium Ylides

3. General Structural Features of Iodonium Ylides

4. Synthetic Applications of Iodonium Ylides

4.1. Reactions of iodonium ylides as carbene precursors

4.2. Cycloaddition reactions of iodonium ylides leading to heterocycles

4.3. Introduction of fluorine using iodonium ylides

4.4. Thiotrifluoromethylation using iodonium ylides

5. Conclusions

6. Acknowledgements

7. References 


\section{Introduction}

Since the beginning of the 21st century, the organic chemistry of hypervalent iodine compounds has experienced an explosive development. ${ }^{1-10}$ Hypervalent iodine reagents are now widely used in organic synthesis as versatile and sustainable reagents whose chemical properties are similar to the heavy metals derivatives, like mercury(II), thallium(III), lead(IV), osmium(VIII) and chromium(VI), but without the toxicity and environmental problems associated with these metals.

Previously we have published three reviews in Arkivoc summarizing synthetic applications of hypervalent iodine reagents ${ }^{11,12}$ and aryliodonium salts. ${ }^{13}$ Aryliodonium ylides, $\mathrm{ArI}^{+}-{ }^{-} \mathrm{CX}_{2}$, where $\mathrm{X}$ is an electron-withdrawing substituent (e.g., carbonyl or sulfonyl group), represent an important class of iodonium compounds with numerous applications in organic synthesis. The chemistry of aryliodonium ylides has been discussed in several older reviews, which mainly summarized the use of ylides as precursors for generation of singlet carbenes or carbenoid species. ${ }^{14-18}$ In the present review, the synthesis and structural studies of iodonium ylides are discussed, and recent developments in their synthetic applications are summarized. The literature coverage is through Spring 2016.

\section{Preparation and Properties of Iodonium Ylides}

The first stable iodonium ylide was prepared from (difluoroiodo)benzene and dimedone by Neiland and co-workers in $1957 .{ }^{19}$ Since then, numerous stable aryliodonium ylides have been prepared and utilized as reagents for organic synthesis.

The vast majority of iodonium ylides have a relatively low thermal stability and can be handled only at low temperatures. The relatively stable dicarbonyl derivatives, $\mathrm{PhIC}(\mathrm{COR})_{2},{ }^{19-23}$ and the disulfonyl derivatives, $\mathrm{PhIC}\left(\mathrm{SO}_{2} \mathrm{R}\right)_{2},{ }^{24-27}$ are generally prepared by a reaction of $\mathrm{PhI}(\mathrm{OAc})_{2}$ with appropriate dicarbonyl compounds or disulfones under basic conditions. In particular, phenyliodonium ylides $\mathbf{2}$ are obtained by the treatment of malonate esters $\mathbf{1}$ with (diacetoxyiodo)benzene in dichloromethane in the presence of $\mathrm{KOH}$ (Scheme 1). ${ }^{22}$ An optimized procedure for the preparation of bis(methoxycarbonyl)(phenyliodonium)methanide $\mathbf{4}$ by a similar reaction of dimethyl malonate $\mathbf{3}$ in acetonitrile was published by the same authors in Organic Syntheses. ${ }^{28}$ Ylides $\mathbf{2}$ and $\mathbf{4}$ can be stored for several weeks at $-20{ }^{\circ} \mathrm{C}$, however, they slowly decompose at room temperature. 


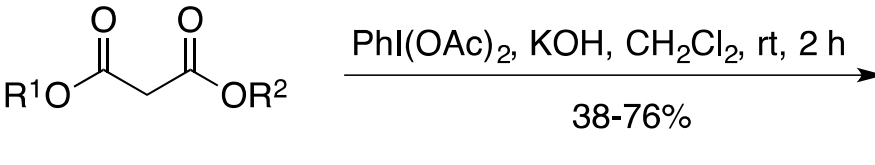

$1 \quad \mathrm{R}^{1}$ and $\mathrm{R}^{2}=\mathrm{Pr}^{\mathrm{i}}, \mathrm{Et}, \mathrm{Bu}^{\mathrm{t}}, \mathrm{Bn}$<smiles>COC(=O)CC(=O)OC</smiles>

3<smiles>[R]OC(=O)C([I-][I+]c1ccccc1)C(=O)O[R]</smiles>

2

Scheme 1. Synthesis of iodonium ylides from malonate esters.

Zhang and co-workers have reported a convenient procedure for the preparation of dimedone-derived iodonium ylide $\mathbf{6}$ in excellent yield by treatment of dimedone 5 with iodosylbenzene in dichloromethane (Scheme 2). ${ }^{29}$ Addition of a catalytic amount of zinc perchlorate $(10 \mathrm{~mol} \%)$ shortens the reaction time to $10 \mathrm{~min}$ with a slightly lower yield $(80 \%)$ yield of ylide 6. Zinc cation acts as a Lewis acid depolymerizing and activating iodosylbenzene.

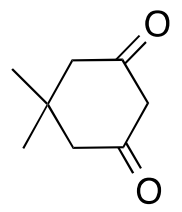

5

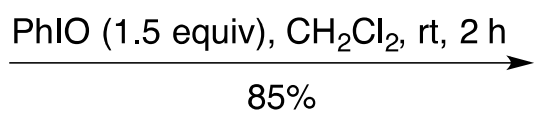

$85 \%$<smiles>COC(=O)C([I+]c1ccccc1)C(=O)OC</smiles>

4

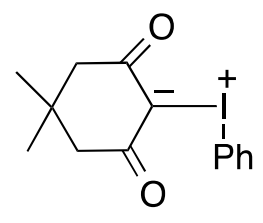

6

Scheme 2. Synthesis of dimedone-derived iodonium ylide 6.

Practical applications of ylides $\mathbf{2 , 4}$ and $\mathbf{6}$ are limited by their poor solubility (insoluble in most organic solvents except DMSO) and low stability. Thermal stability and solubility of iodonium ylides can be significantly improved by introduction of a coordinating substituent in the ortho position of the phenyl ring. ${ }^{30}$ In particular, 2-alkoxyphenyliodonium ylides 9 derived from malonate methyl ester and bearing an ortho alkoxy substituent on the phenyl ring, can be synthesized from commercially available 2-iodophenol 7 via diacetates 8 according to the procedure shown in Scheme 3. Ylides 9 are relatively stable compounds with excellent solubility in dichloromethane, chloroform, or acetone (e.g., the solubility of ylide 9, $\mathrm{R}=\mathrm{Pr}$, in dichloromethane is $0.56 \mathrm{~g} / \mathrm{mL}) .{ }^{31}$ The higher thermal stability and a useful reactivity pattern are also characteristic for the dimedone-derived o-alkoxyphenyliodonium ylides 10, which are prepared similarly by the reaction of diacetates $\mathbf{8}$ with dimedone $\mathbf{5}$ in methanol in the presence of $\mathrm{KOH}$ (Scheme 3). ${ }^{32}$ 

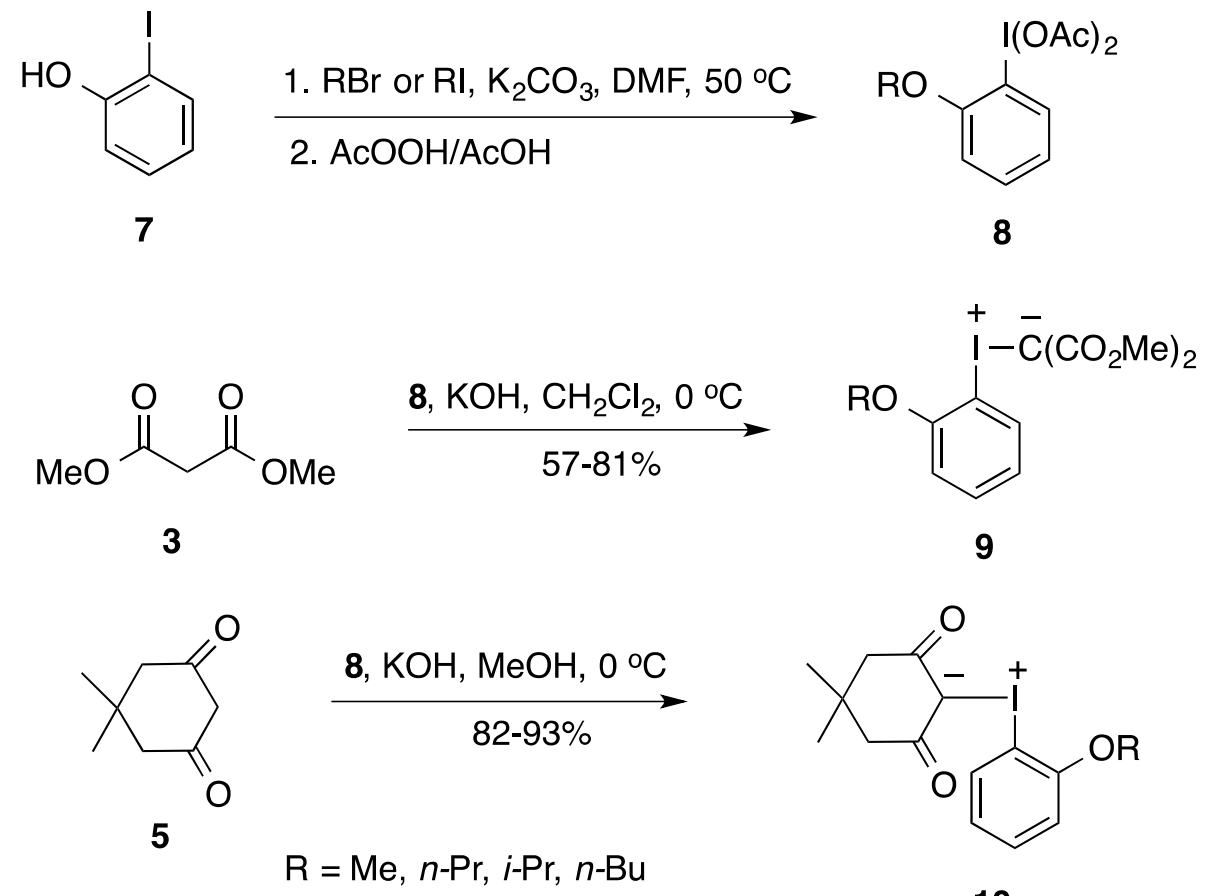

10

Scheme 3. Synthesis of 2-alkoxyphenyliodonium ylides.

Recently, several stable ortho-substituted iodonium ylides 13 have been prepared by reactions of $\beta$-dicarbonyl compounds 11 with benziodoxole 12 in the absence of any base (Scheme 4). ${ }^{33}$ The new iodonium ylides 12 bearing an ortho-propan-2-ol group in the phenyl ring are surprisingly stable for acyclic iodonium ylides owing to the intramolecular coordination of iodine by the hydroxyl group. Not only are these iodonium ylides stable at room temperature, but they could be purified by column chromatography on silica gel.

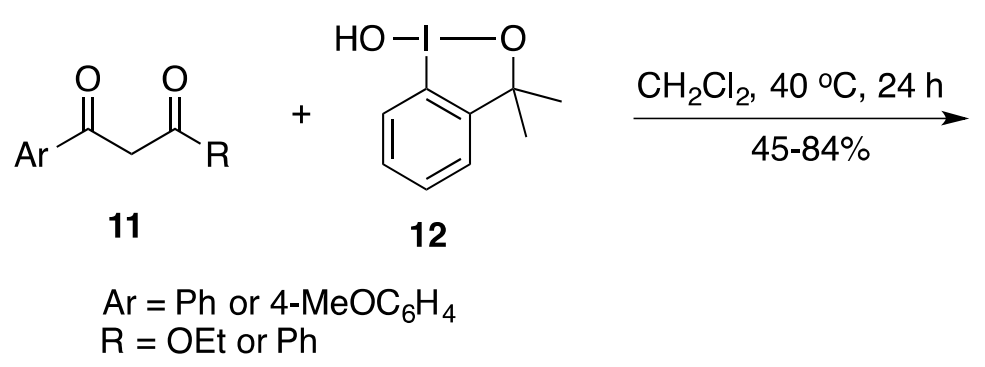

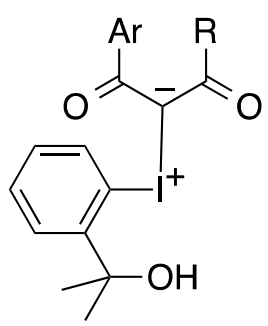

13

Scheme 4. Synthesis of iodonium ylides 13 from benziodoxole 12.

Cyclic iodonium ylides, in which the iodonium atom is incorporated in a five-membered ring, have even higher thermal stability. The unusually stable cyclic iodonium ylides $\mathbf{1 6}$ were 
prepared via the intramolecular transylidation of the acyclic ylides $\mathbf{1 5}$, which were synthesized by the known method from $\beta$-diketones 14 (Scheme 5 ). ${ }^{34}$<smiles>[R]C(=O)CC(=O)c1ccccc1I</smiles>

14

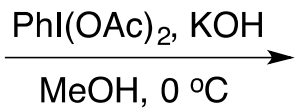

$\mathrm{OH}, \mathrm{O}^{\circ} \mathrm{C}$<smiles></smiles>

15

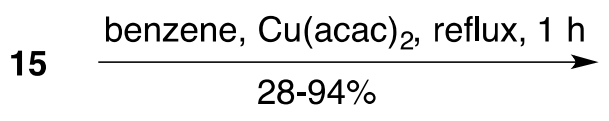<smiles>[R]C(=O)C1=[I+]c2ccccc2C1=O</smiles>

16

Scheme 5. Synthesis of cyclic iodonium ylides $\mathbf{1 6 .}$

Bis(perfluoroalkanesulfonyl)(phenyliodonium)methanides $\quad 17$, synthesized from (diacetoxyiodo)benzene and bis[(perfluoroalkyl)sulfonyl]methane (Scheme 6), also have a relatively high thermal stability; they can be stored without decomposition at room temperature for several months. ${ }^{26}$ The nonsymmetric, cyano[(perfluoroalkyl)sulfonyl]-substituted ylides 18 (Scheme 6) ${ }^{25}$ or bis(fluorosulfonyl)(phenyliodonium)methanide, $\mathrm{PhIC}\left(\mathrm{SO}_{2} \mathrm{~F}\right)_{2},{ }^{35}$ were prepared from (diacetoxyiodo)benzene and appropriate bis(sulfonyl)methanes as starting materials.

$$
\begin{gathered}
\mathrm{Phl}(\mathrm{OAC})_{2}+\mathrm{CH}_{2}\left(\mathrm{SO}_{2} \mathrm{R}\right)_{2} \quad \mathrm{CH}_{2} \mathrm{Cl}_{2}, 20 \text { to } 40{ }^{\circ} \mathrm{C}, 12-24 \mathrm{~h} \\
\mathrm{R}=\mathrm{CF}_{3}, \mathrm{C}_{4} \mathrm{~F}_{9} \text { or } 2 \mathrm{R}=\left(\mathrm{CF}_{2}\right)_{3}
\end{gathered}
$$

Scheme 6. Preparation of bis(perfluoroalkanesulfonyl)(phenyliodonium)methanides.

Cardinale and Ermert have developed a simplified method for preparing aryliodonium ylides in a one-pot procedure starting from the respective aryl iodides. ${ }^{23}$ In particular, aryliodonium ylides 19 were synthesized by a two-step, one-pot procedure shown in Scheme 7. Aryl iodides were first oxidized with $m$-chloroperoxobenzoic acid ( $m \mathrm{CPBA}$ ) in dichloromethane 
followed by the addition of Meldrum's acid (2,2-dimethyl-1,3-dioxane-4,6-dione) and $\mathrm{KOH}$ to give ylides 19 in moderate yields. ${ }^{23}$

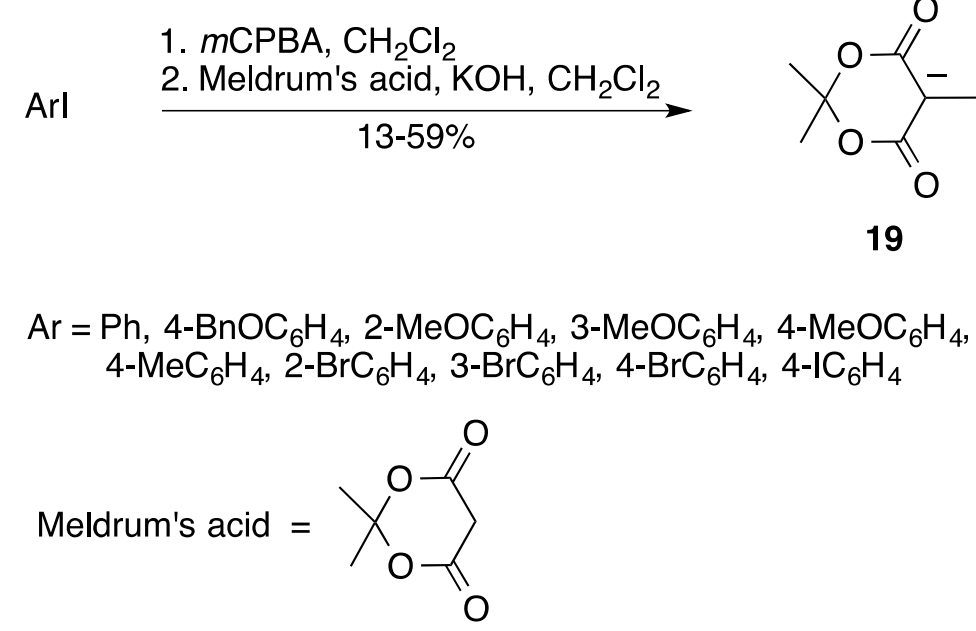

Scheme 7. Preparation of aryliodonium ylides in one-pot starting from aryl iodides.

Ochiai and co-workers developed a new synthetic approach to iodonium ylides 21 by the intermolecular transylidation reactions between halonium ylides under thermal or catalytic conditions (Scheme 8). ${ }^{36,37}$ The transylidation of bromonium 20 to iodonium 21 ylides proceeds under thermal conditions and probably involves generation of a reactive carbene intermediate. ${ }^{36}$ Heating of phenyliodonium ylide 22 with iodoarenes in the presence of $5 \mathrm{~mol} \%$ of rhodium(II) acetate as a catalyst results in the transfer of the bis(trifluoromethylsulfonyl)methylidene group to the iodine(I) atom of iodoarene to afford substituted aryliodonium ylides $\mathbf{2 3}$ in good yields. ${ }^{37}$

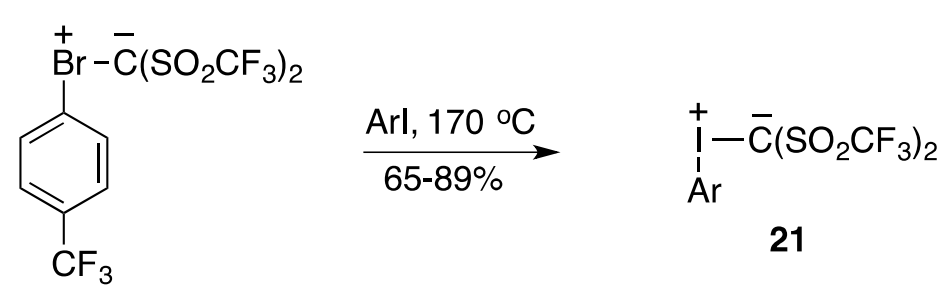

$20 \quad \mathrm{Ar}=\mathrm{Ph}, 4-\mathrm{MeOC}_{6} \mathrm{H}_{4}, 4-\mathrm{MeC}_{6} \mathrm{H}_{4}, 4-\mathrm{FC}_{6} \mathrm{H}_{4}$, 4- $\mathrm{ClC}_{6} \mathrm{H}_{4}, 4-\mathrm{BrC}_{6} \mathrm{H}_{4}, 4-\mathrm{CF}_{3} \mathrm{C}_{6} \mathrm{H}_{4}$

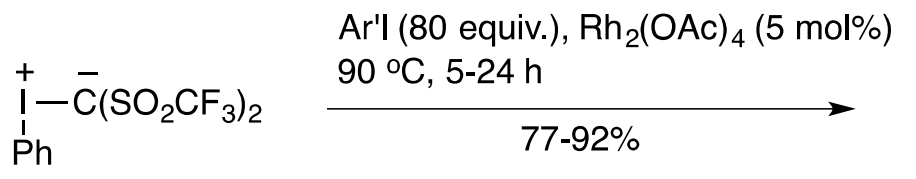

22

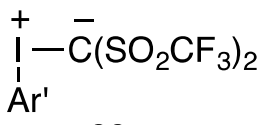

23

$$
\begin{aligned}
A r^{\prime}= & 4-\mathrm{MeOC}_{6} \mathrm{H}_{4}, 2-\mathrm{MeC}_{6} \mathrm{H}_{4}, 3-\mathrm{MeC}_{6} \mathrm{H}_{4}, 3,5-\mathrm{Me}_{2} \mathrm{C}_{6} \mathrm{H}_{3}, \\
& 4-\mathrm{ClC}_{6} \mathrm{H}_{4}, 4-\mathrm{BrC}_{6} \mathrm{H}_{4}, 4-\mathrm{FC}_{6} \mathrm{H}_{4}, 4-\mathrm{CF}_{3} \mathrm{C}_{6} \mathrm{H}_{4}
\end{aligned}
$$

Scheme 8. Preparation of aryliodonium ylides by the intermolecular transylidation reactions. 
Iodonium ylides derived from phenolic substrates represent an important class of zwitterionic iodonium compounds. ${ }^{17,18}$ The preparation of phenolic iodonium ylides $\mathbf{2 4}$ was first reported in 1977 via a reaction of para-substituted phenols with (diacetoxyiodo)benzene followed by treatment with pyridine (Scheme 9). ${ }^{38}$ The system of an iodonium phenolate is stabilized by the presence of at least one electron-withdrawing substituent on the aromatic ring. Monosubstituted iodonium phenolates $\mathbf{2 4}$ are relatively unstable and easily rearrange to iodo ethers $\mathbf{2 5}$ under heating.<smiles>[R]c1ccc(O)cc1</smiles>

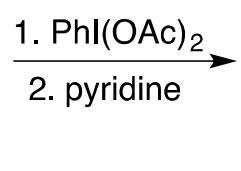

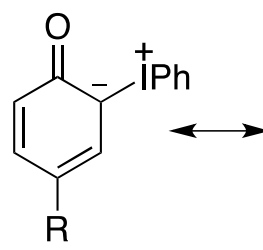
$\mathrm{R}=\mathrm{NO}_{2}$ or $\mathrm{CHO}$<smiles></smiles>

24 heat<smiles>[R]c1ccc(Oc2ccccc2)c(I)c1</smiles>

25

Scheme 9. Preparation and rearrangement of phenolic iodonium ylides.

Mixed phosphonium-iodonium ylides represent a useful class of reagents that combine in one molecule synthetic advantages of a phosphonium ylide and an iodonium salt. The preparation of the tetrafluoroborate derivatives $\mathbf{2 7}$ by the reaction of phosphonium ylides $\mathbf{2 6}$ with (diacetoxyiodo)benzene in the presence of $\mathrm{HBF}_{4}$ was first reported by Neilands and Vanag in 1964. ${ }^{39}$ Later, in 1984, Moriarty and co-workers reported the preparation of several new tetrafluoroborate derivatives $\mathbf{2 9}$ and X-ray crystal structure for one of the products. ${ }^{40}$ The triflate 29 and tosylate 30 derivatives of phosphonium-iodonium ylides have been prepared in good yields by the reaction of phosphonium ylides $\mathbf{2 8}$ with the pyridine complex of iodobenzene ditriflate, $\mathrm{PhI}(\mathrm{OTf})_{2} \cdot 2 \mathrm{Py},{ }^{41}$ or with [hydroxy(tosyloxy)iodo]benzene, respectively (Scheme 10). ${ }^{42-45}$ The analogous mixed arsonium-iodonium ylides were synthesized using a similar procedure. $^{45}$ Preparation of heteroaryl-substituted phosphonium-iodonium ylides was also reported. $^{46}$

The unstable monocarbonyl iodonium ylides 32 can be generated from (Z)-(2acetoxyvinyl)iodonium salts $\mathbf{3 1}$ by ester exchange reaction with lithium ethoxide in tetrahydrofuran at low temperature (Scheme 11). ${ }^{1} \mathrm{H}$ NMR measurements indicate that ylides 32 are stable up to $-30{ }^{\circ} \mathrm{C}$, and they can be conveniently used in subsequent transformations without isolation. $^{47-52}$ 
<smiles>[R]C(=O)C=[Pb]</smiles>

$\mathrm{R}=\mathrm{OEt}, \mathrm{Ph}$

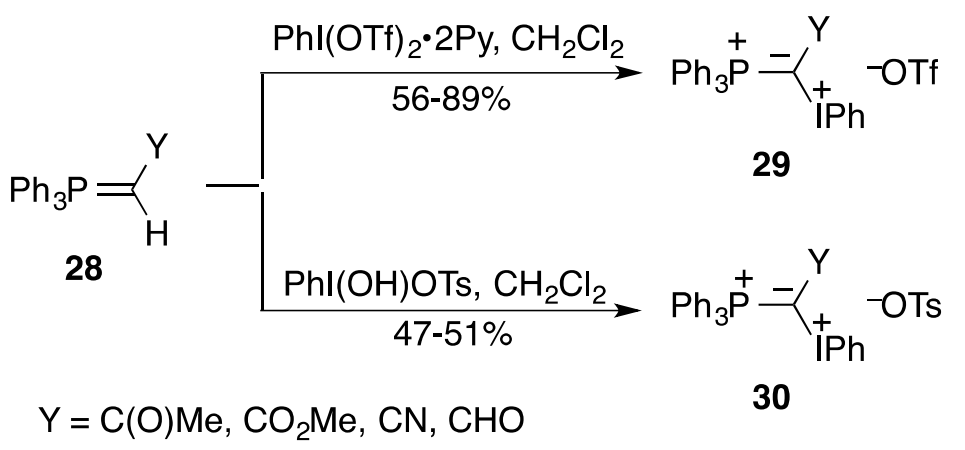

Scheme 10. Preparation of mixed phosphonium-iodonium ylides.

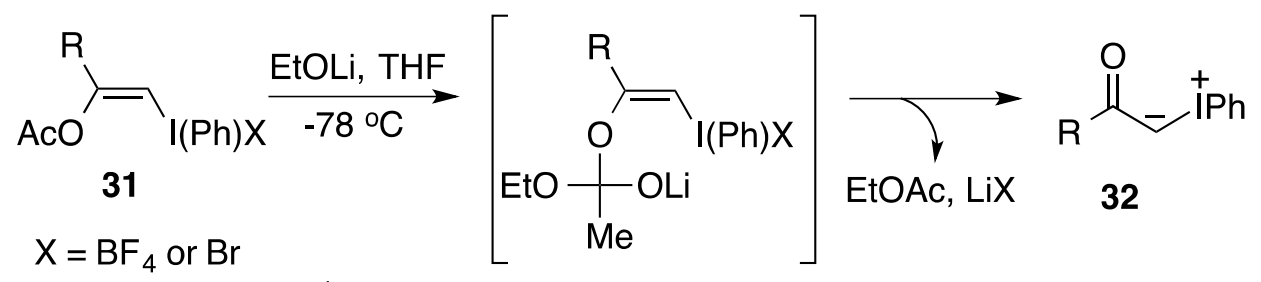

Scheme 11. Generation of monocarbonyl iodonium ylides.

\section{General Structural Features of Iodonium Ylides}

Single crystal X-ray structures have been reported for the following iodonium ylides: 3phenyliodonio-1,2,4-trioxo-1,2,3,4-tetrahydronaphthalenide $33,{ }^{53}$ 3-phenyliodonio-2,4-dioxo1,2,3,4-tetrahydro-1-oxanaphthalenide $34,{ }^{53}$ mixed phosphonium-iodonium tetrafluoroborates $\mathbf{3 5}^{40}$ and 36, ${ }^{43}$ mixed arsonium-iodonium tetrafluoroborate $37,{ }^{54}$ mixed phosphonium iodonium triflate 38, ${ }^{42}$ phenyliodonium bis(trifluoromethanesulfonyl)methide $39,{ }^{24}$ cyclic iodonium ylide $\mathbf{4 0},{ }^{34}$ 2-methoxyphenyliodonium bis(methoxycarbonyl)methanide $\mathbf{4 1},{ }^{31}$ and the pseudocyclic ortho-substituted iodonium ylides $\mathbf{4 2}^{33}$ (Figure 1). According to X-ray data, the geometry of aryliodonium ylides is similar to the geometry of iodonium salts with a $\mathrm{C}-\mathrm{I}-\mathrm{C}$ angle close to $90^{\circ}$, which is indicative of a zwitterionic nature of the ylidic $\mathrm{C}-\mathrm{I}$ bond. In particular, phenyliodonium ylide 39 has a geometry typical for an iodonium ylide with the $\mathrm{I}-\mathrm{C}$ ylidic bond length of about $1.9 \AA$ and an $\mathrm{C}-\mathrm{I}-\mathrm{C}$ bond angle of $98^{\circ} .{ }^{24} \mathrm{X}$-ray structural analysis for cyclic ylide $\mathbf{4 0}$ reveals a 
distorted five-membered ring with the ylidic bond length about $2.1 \AA$ and a $\mathrm{C}-\mathrm{I}-\mathrm{C}$ bond angle of $82^{\circ}$, which is smaller than the usual $90^{\circ} .^{34}$ 2-Methoxyphenyliodonium bis(methoxycarbonyl)methanide 41 in solid state has a polymeric, asymmetrically bridged structure with a hexacoordinated geometry around the iodine centers formed by two short C-I bonds [2.117 $\AA$ for $\mathrm{I}-\mathrm{C}(\mathrm{Ph})$ and $2.039 \AA$ for $\mathrm{I}-\mathrm{C}($ malonate $)]$ and two relatively long iodine-oxygen intramolecular interactions between iodine and the oxygen atom of the ortho substituent $(2.928 \AA)$ and the carbonyl oxygen atom of the methoxycarbonyl group (3.087 $\AA$ ). In addition, a relatively weak intermolecular I-O secondary interaction of $2.933 \AA$ between the iodine center and the carbonyl oxygen atom of the neighboring molecule is also present in the solid state structure of $41{ }^{31}$ Structure of the unusually stable pseudocyclic iodonium ylide $\mathbf{4 2}$ bearing an ortho-propan-2-ol group in the phenyl ring is characterized by the presence of additional intramolecular coordination of iodine by the hydroxyl group. ${ }^{33}$<smiles>O=C1C(=O)C([I+]c2ccccc2)C(=O)c2ccccc21</smiles>

33

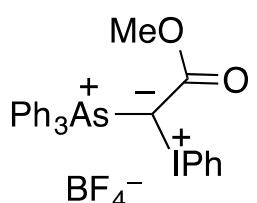

37<smiles>COc1ccccc1[I+]C(C)=O</smiles>

41

1<smiles>O=C1Oc2ccccc2C(=O)C1=[I+]Cc1ccccc1</smiles>

34<smiles></smiles>

38<smiles>Cc1ccc(C(=O)C([I-]c2ccccc2C)[P+](c2ccccc2)c2ccccc2)cc1</smiles>

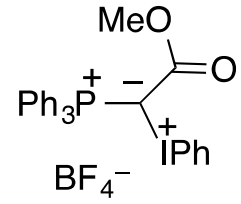

36<smiles>CC(=O)C1[I-]c2ccccc2C1=O</smiles>

40

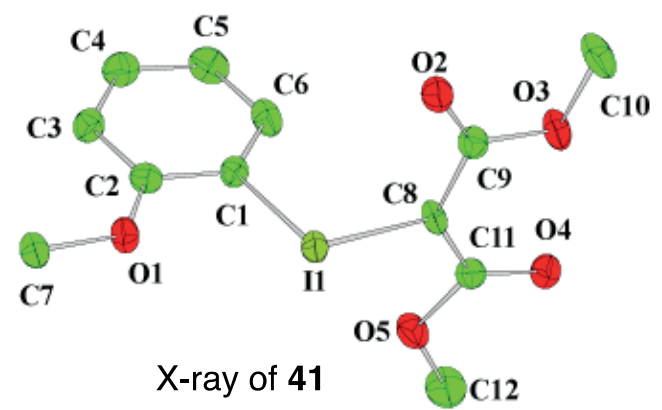

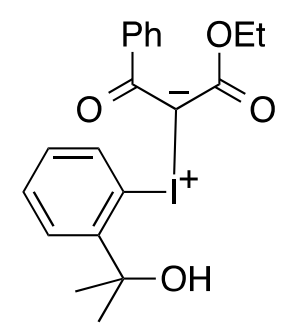

42

Figure 1. Iodonium ylides structurally characterized by single crystal X-ray diffractometry.

The structures of iodonium ylides have also been studied by various spectroscopic techniques. For example, an interesting Moessbauer spectral study has been published by 
Nishimura and coauthors. ${ }^{55}$ This study, in particular, confirmed that the ylidic I-C bond is mostly zwitterionic in nature.

In should be mentioned that the ylidic bond in iodonium ylides is commonly shown in the literature as the $\mathrm{I}=\mathrm{C}$ double bond. However, according to high level computational study using adaptive natural density partitioning bond modeling technique (AdNDP), a double bond between iodine atom and other elements does not exist and the actual bonding in iodonium ylides has a dative $2 \mathrm{c}-2 \mathrm{e}$ nature. ${ }^{56}$

\section{Synthetic Applications of Iodonium Ylides}

\subsection{Reactions of iodonium ylides as carbene precursors}

Iodonium ylides can serve as efficient precursors to the respective carbene intermediates under thermal, photochemical, or catalytic conditions. A detailed discussion of the reaction mechanisms and synthetic applications of iodonium ylides as carbene precursors can be found in the earlier reviews. ${ }^{14-18}$

Bis(methoxycarbonyl)(phenyliodinio)methanide 4, the most common iodonium ylide derived from malonate methyl ester, has found synthetic applications in the $\mathrm{C}-\mathrm{H}$ insertion reactions, ${ }^{57-61}$ and in the cyclopropanation of alkenes, ${ }^{22,28,62-66}$ including enantioselective cyclopropanations in the presence of chiral rhodium complexes. ${ }^{15,67,68}$ Representative examples of these reactions are shown in Scheme 12 and include the $\mathrm{BF}_{3}$-catalyzed bis(carbonyl)alkylation of 2-alkylthiophenes $\mathbf{4 3},{ }^{58}$ and the optimized procedure for rhodiumcatalyzed cyclopropanation of styrene $44 .^{28}$

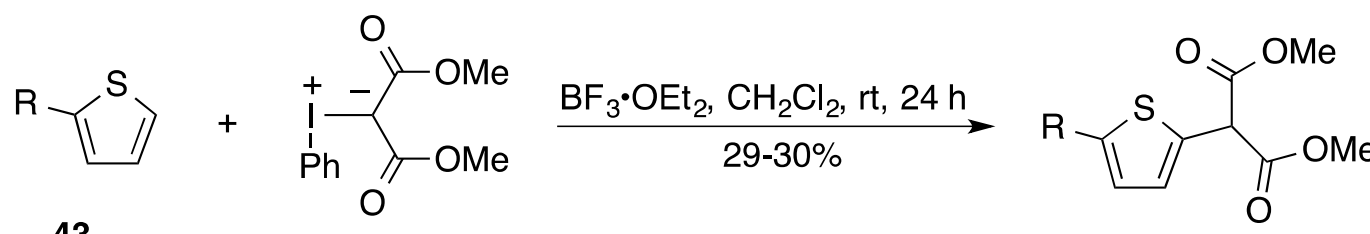

43

$\mathrm{R}=\mathrm{Me}$ or $\mathrm{Et}$

4

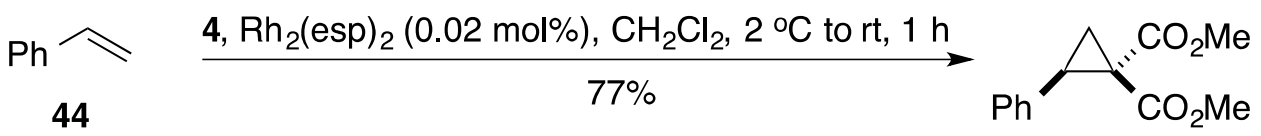

$\mathrm{Rh}_{2}(\mathrm{esp})_{2}=\operatorname{bis}\left[\right.$ rhodium $\left(\alpha, \alpha, \alpha^{\prime}, \alpha^{\prime}\right.$-tetramethyl-1,3-benzenedipropionic acid $\left.)\right]$

Scheme 12. Reactions of iodonium ylide 4 as carbene precursor.

A particularly useful reagent in these carbenoid reactions is the highly soluble and reactive iodonium ylide $\mathbf{4 5}$ derived from malonate methyl ester and bearing an ortho methoxy 
substituent on the phenyl ring. ${ }^{31}$ This reagent shows higher reactivity than common phenyliodonium ylides in the $\mathrm{Rh}$-catalyzed cyclopropanation, $\mathrm{C}-\mathrm{H}$ insertion, and transylidation reactions under homogeneous conditions. Examples of the carbenoid reactions of ylide $\mathbf{4 5}$ are shown in Scheme 13. ${ }^{31}$

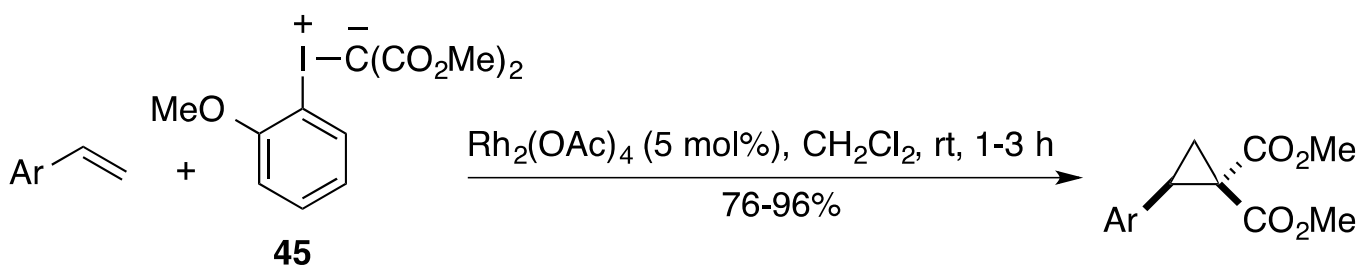

$\mathrm{Ar}=\mathrm{Ph}, 4-\mathrm{MeC}_{6} \mathrm{H}_{4}, 4-\mathrm{CF}_{3} \mathrm{C}_{6} \mathrm{H}_{4}, 4-\mathrm{BrC}_{6} \mathrm{H}_{4}, 4-\mathrm{ClC}_{6} \mathrm{H}_{4}, 3-\mathrm{MeC}_{6} \mathrm{H}_{4}, 4-\mathrm{MeOC}_{6} \mathrm{H}_{4}$, etc.

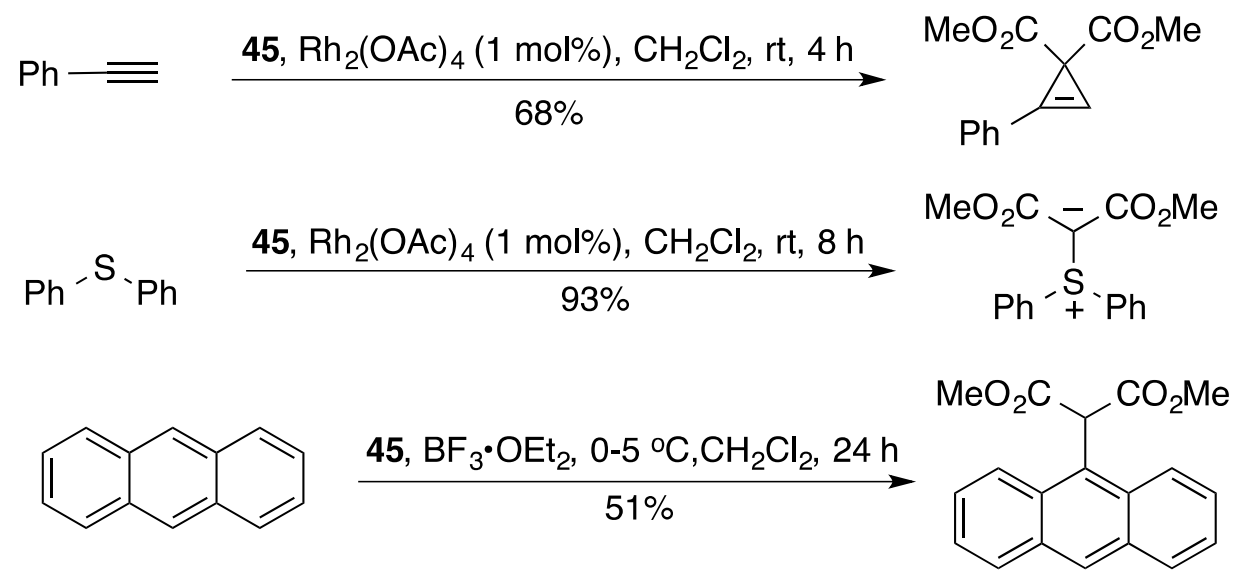

Scheme 13. Carbenoid reactions of the soluble iodonium ylide $\mathbf{4 5 .}$

The carbenoid reactions of iodonium ylides can be effectively catalyzed by rhodium(II) or copper complexes. ${ }^{14-16}$ The product composition in the rhodium(II)-catalyzed reactions of iodonium ylides was found to be identical to that of the corresponding diazo compounds, which confirms that mechanisms of both processes are similar and involve metallocarbenes as key intermediates. ${ }^{69}$ Hadjiarapoglou and co-workers have recently reported a mechanistic study of the reactions of cyclic $\beta$-dicarbonyl phenyliodonium ylide with various substituted styrenes under $\mathrm{Rh}_{2}(\mathrm{OAc})_{4}$ catalysis confirming the carbenoid mechanism of these reactions. ${ }^{70}$ Examples of the transition metal-catalyzed carbenoid reactions of iodonium ylides are illustrated by the following publications: $\mathrm{Rh}(\mathrm{II})$ - or $\mathrm{Cu}(\mathrm{I})$-catalyzed cyclopropanation reactions using the unstable ylides $\mathrm{PhIC}(\mathrm{H}) \mathrm{NO}_{2}{ }^{71}$ and $\mathrm{PhIC}\left(\mathrm{CO}_{2} \mathrm{Me}\right) \mathrm{NO}_{2}{ }^{72-74}$ generated in situ from nitromethane and methyl nitroacetate; $\mathrm{Rh}(\mathrm{II})$-catalyzed three-component coupling of an ether with a nitromethanederived carbenoid generated from $\mathrm{PhIC}(\mathrm{H}) \mathrm{NO}_{2} ;{ }^{75} \mathrm{Rh}(\mathrm{II})$ - or $\mathrm{Cu}(\mathrm{II})$-catalyzed insertion of carbene into alkenyl $\mathrm{C}-\mathrm{H}$ bond in flavones, ${ }^{76}$ and highly phenylated ethylenes; ${ }^{77} \mathrm{Rh}(\mathrm{II})$ catalyzed reaction of iodonium ylides with conjugated dienes and $\alpha, \beta$-unsaturated carbonyl compounds leading to efficient synthesis of dihydrofurans, oxazoles, and dihydrooxepines; ${ }^{78}$ 
synthesis of various heterocycles by $\mathrm{Rh}$ (II)-catalyzed reactions of iodonium ylides with vinyl ethers, carbon disulfide, alkynes, and nitriles; ${ }^{66} \mathrm{Rh}$ (II)-catalyzed reaction of iodonium ylides with electron-deficient and conjugated alkynes leading to substituted furans; ${ }^{79}$ efficient synthesis of $\beta$-substituted $\alpha$-haloenones by $\mathrm{Rh}$ (II)-catalyzed reactions of iodonium ylides with benzyl halides and acid halides; ${ }^{80,81} \mathrm{Rh}$ (II)- or $\mathrm{Cu}$ (II)-catalyzed generation/rearrangement of onium ylides of allyl and benzyl ethers via iodonium ylides; ${ }^{82}$ and $\mathrm{Rh}(\mathrm{II})-$ or $\mathrm{Cu}(\mathrm{II})$-catalyzed stereoselective cycloaddition of disulfonyl iodonium ylides with alkenes leading to 1,2,3-trisubstituted benzocyclopentenes ${ }^{83}$ or functionalized indanes. ${ }^{84-86}$

Moriarty and co-workers have investigated the intramolecular cyclopropanation of iodonium ylides to the tricyclic ketones in the presence of copper(I) chloride and also in the absence of conventional metal calalysts. ${ }^{87}$ Synthetic utility of this methodology has been demonstrated by conversion of ylide 46 to a mixture of diastereomeric products 47 and 48 related to prostaglandins and vitamin $\mathrm{D}$, respectively (Scheme 14).<smiles>COC(=O)C(C(=O)CC(O)/C=C/C=C/S)[P+](=O)c1ccccc1</smiles>

46

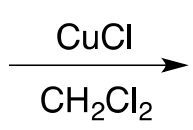

RO

\section{( \pm ) 47}<smiles></smiles>

47

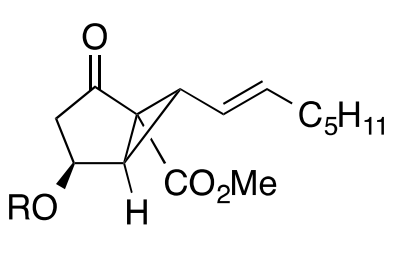

$( \pm) 48$

Scheme 14. Intramolecular cyclization of phenyliodonium ylide $\mathbf{4 6}$.

The metal-catalyzed carbenoid reactions of iodonium ylides have been applied in asymmetric reactions. ${ }^{60,64,73,74,88}$ For example, the copper(II)-catalyzed intramolecular C-H insertion of phenyliodonium ylide $\mathbf{4 9}$ in the presence of chiral ligands followed by hydrolysis and decarboxylation affords product $\mathbf{5 0}$ in moderate yield with up to $72 \%$ ee (Scheme 15). ${ }^{60}$

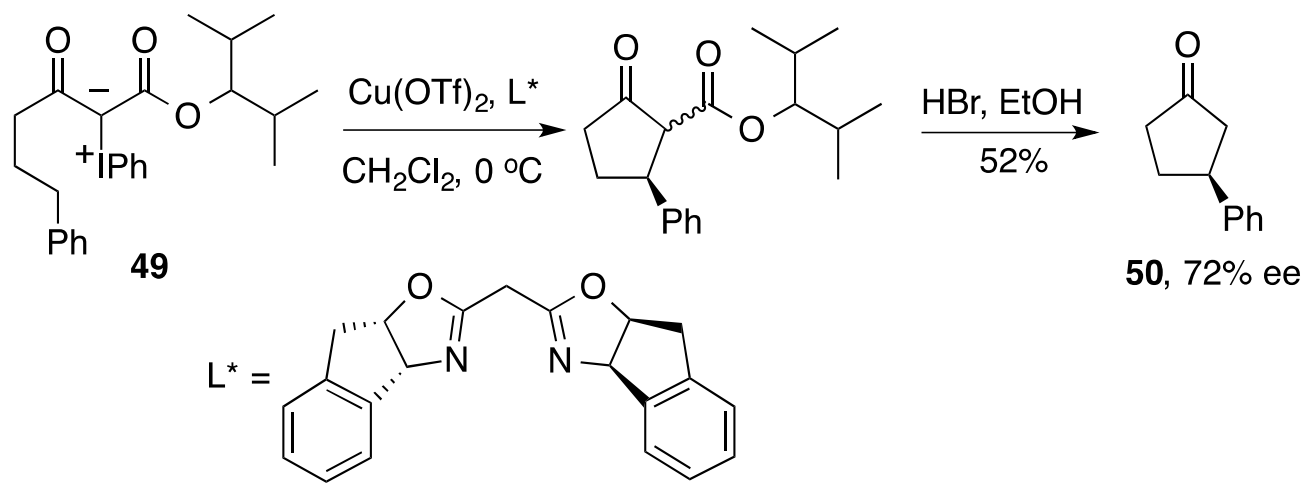

Scheme 15. Enantioselective intramolecular $\mathrm{C}-\mathrm{H}$ insertion of phenyliodonium ylide 49. 
Charette and co-workers have developed a $\mathrm{Cu}(\mathrm{I})$-catalyzed asymmetric cyclopropanation of alkenes with an iodonium ylide generated in situ from iodosylbenzene and methyl nitroacetate (Scheme 16). ${ }^{74}$ High enantioselectivity (up to 98\% ee) and diastereoselectivity (95:5 dr trans/cis) were achieved for a wide range of aryl- or alkyl-substituted alkenes 51. This synthetically useful reaction allows facile preparation of various 1-nitrocyclopropyl carboxylates $\mathbf{5 2}$ which can be further transformed into the corresponding substituted cyclopropane amino acids and aminocyclopropanes.

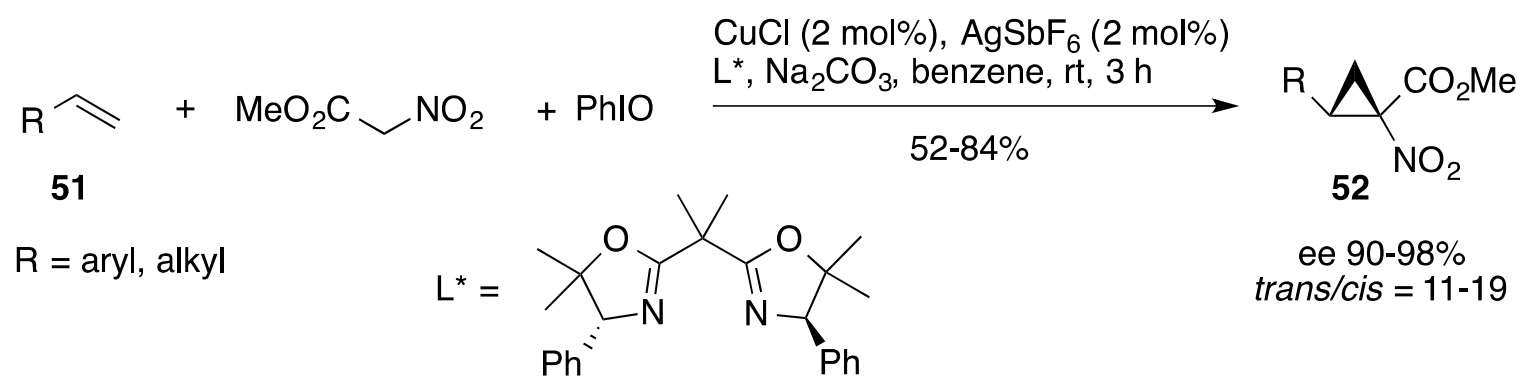

Scheme 16. Preparation of 1-nitrocyclopropyl carboxylates by enantioselective cyclopropanation of alkenes.

Ochiai and co-workers have reported several useful reactions of the unstable monocarbonyl iodonium ylides $\mathbf{5 4}$, which can be quantitatively generated from (Z)-(2acetoxyvinyl)iodonium salts $\mathbf{5 3}$ via an ester exchange reaction with lithium ethoxide in THF at low temperature (Scheme 17). ${ }^{47-49}$ Ylide 54, generated in situ from iodonium salts 53, reacts with aldehydes in THF/DMSO at low temperature to afford $\alpha, \beta$-epoxy ketones $\mathbf{5 5}$ with the predominant formation of the trans isomers. A Hammett reaction constant $(\rho=2.95)$ for this reaction indicates that monocarbonyl iodonium ylides $\mathbf{5 4}$ are moderately nucleophilic in nature. ${ }^{49}$

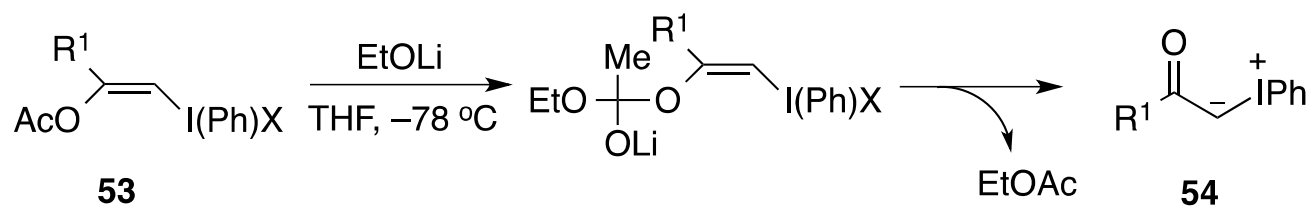

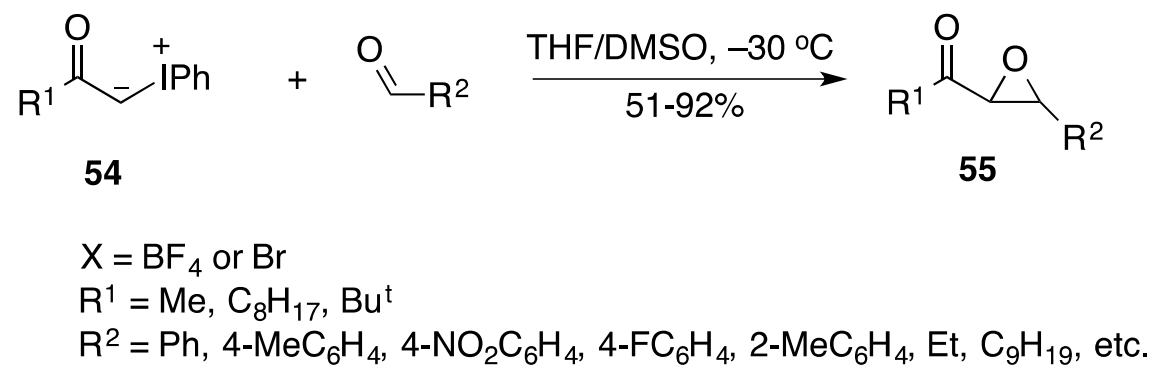

Scheme 17. Reactions of monocarbonyl iodonium ylides 54 with aldehydes. 
Monocarbonyl iodonium ylides, generated in situ from iodonium salts 53, undergo alkylidene transfer reactions to activated imines 56 yielding 2-acylaziridines 57 in good yields (Scheme 18). The stereochemical outcome of this aziridination is dependent on both the activating groups of the imines and the reaction solvents; for example, the aziridination of $N$ (2,4,6-trimethylbenzenesulfonyl)imines in THF affords cis-aziridines as a major product, while that of $N$-benzoylimines in THF/DMSO or THF gives the trans isomer stereoselectively. ${ }^{47,48}$

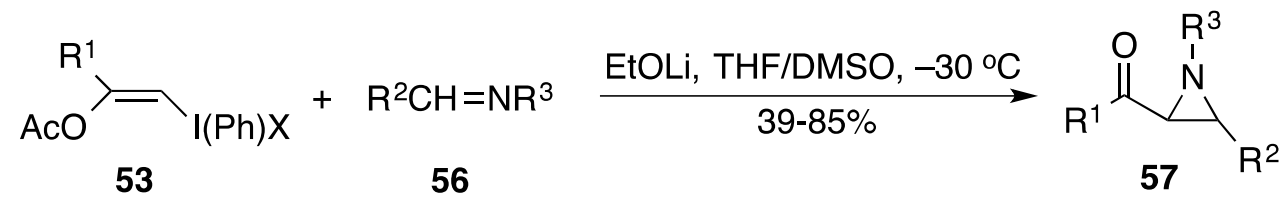

$$
\begin{aligned}
& \mathrm{X}=\mathrm{BF}_{4} \text { or } \mathrm{Br} \\
& \mathrm{R}^{1}=\mathrm{Me}, \mathrm{C}_{8} \mathrm{H}_{17}, \mathrm{Bu}^{\mathrm{t}} \\
& \mathrm{R}^{2}=\mathrm{Ph}, \mathrm{R}^{3}=\mathrm{SO}_{2} \mathrm{Ph} ; \mathrm{R}^{2}=\mathrm{Ph}, \mathrm{R}^{3}=\mathrm{COPh} ; \mathrm{R}^{2}=\mathrm{Ph}, \mathrm{R}^{3}=\mathrm{SO}_{2} \mathrm{Me} ; \text { etc. }
\end{aligned}
$$

Scheme 18. Preparation of 2-acylaziridines 57 using monocarbonyl iodonium ylides.

Miyamoto and co-workers have investigated reactions of $\beta$-butoxycarbonyliodonium ylides, Darzens reagent analogues, which were prepared by the ester exchange reaction of $\beta$ butoxy- $\beta$-acyloxyvinyl- $\lambda^{3}$-iodane $\mathbf{5 8}$ with lithium bases. ${ }^{52}$ The iodonium ylide generated in situ from 58 cleanly undergoes Darzens condensation with aromatic aldehydes to selectively give the trans epoxyesters 59 (Scheme 19).

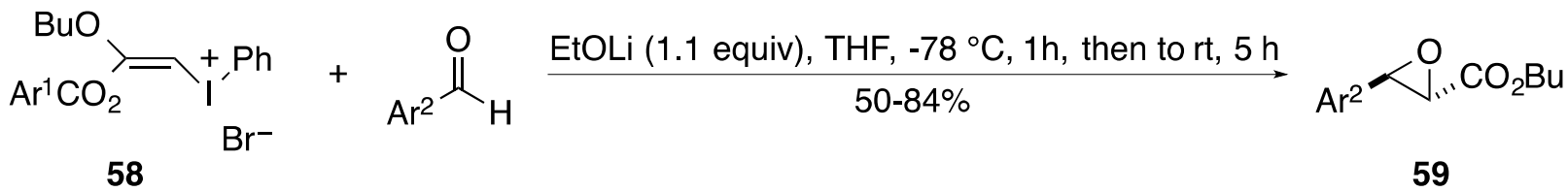

$$
\begin{aligned}
& \mathrm{Ar}^{1}=\mathrm{Ph}, 4-\mathrm{MeC}_{6} \mathrm{H}_{4}, 4-\mathrm{CF}_{3} \mathrm{C}_{6} \mathrm{H}_{4} \\
& \mathrm{Ar}^{2}=\mathrm{Ph}, 4-\mathrm{MeC}_{6} \mathrm{H}_{4}, 2-\mathrm{MeC}_{6} \mathrm{H}_{4}, 4-\mathrm{FC}_{6} \mathrm{H}_{4}, 4-\mathrm{ClC}_{6} \mathrm{H}_{4}, 3-\mathrm{ClC}_{6} \mathrm{H}_{4}, 4-\mathrm{CF}_{3} \mathrm{C}_{6} \mathrm{H}_{4}, 4-\mathrm{CNC}_{6} \mathrm{H}_{4}, 4-\mathrm{MeCO}_{2} \mathrm{C}_{6} \mathrm{H}_{4}
\end{aligned}
$$

Scheme 19. Darzens-type condensation of alkenyliodonium salt with aromatic aldehydes.

Murphy and co-workers have investigated the suitability of monocarbonyl iodonium ylides as metallocarbene precursors. ${ }^{89}$ They have developed a new method for generating monocarbonyl iodonium ylides 61 in situ by treatment of phosphonium ylides $\mathbf{6 0}$ with iodosylbenzene. Ylides $\mathbf{6 1}$ were subsequently intercepted by transition-metal catalysts to generate metallocarbenes, which then underwent either dimerization or cyclopropanation reactions with alkenes (Scheme 20). Though the authors were unable to improve the yields of cyclopropanes 62 to be synthetically viable, this study proves that monocarbonyl iodonium ylides $\mathbf{6 1}$ can serve as metallocarbene precursors. 


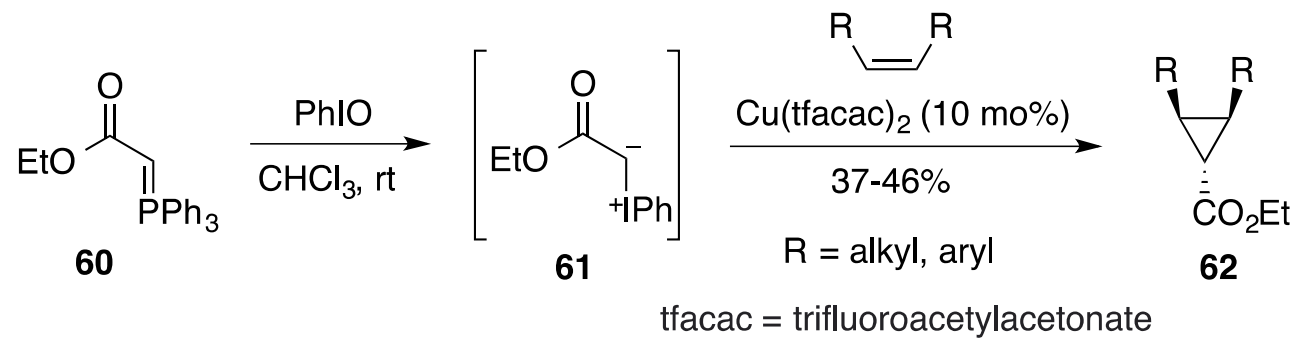

Scheme 20. Reactions of monocarbonyl iodonium ylides as metallocarbene precursors.

The mixed phosphonium-iodonium ylides represent a useful class of reagents that combine in one molecule synthetic advantages of a phosphonium ylide and an iodonium salt. ${ }^{42,44-}$ 46,54,90-95 For example, phosphorane-derived phenyliodonium tosylate $\mathbf{6 3}$ reacts with soft nucleophiles, such as iodide, bromide, benzenesulfinate, thiocyanate, and thiophenolate anions, with a selective formation of the respective $\alpha$-functionalized phosphonium ylides 64 (Scheme 21), which can be further converted to alkenes (e.g., 65) by the Wittig reaction with aldehydes. ${ }^{44}$ The analogous arsonium-iodonium ylides have a similar reactivity toward nucleophiles. ${ }^{45,54,96}$

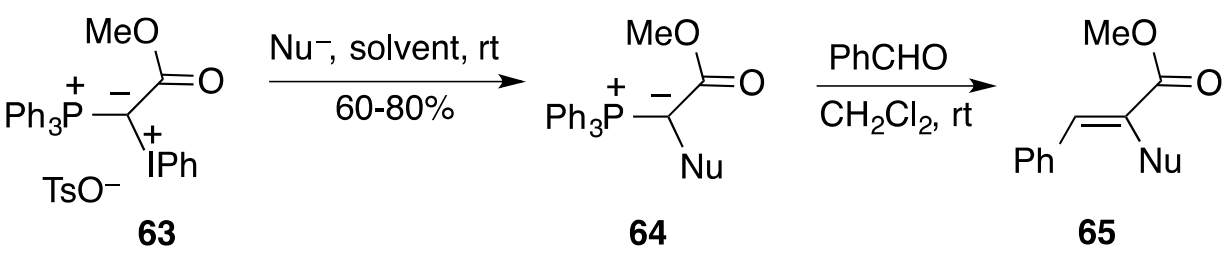

$\mathrm{Nu}=\mathrm{I}, \mathrm{Br}, \mathrm{PhS}, \mathrm{SCN}, \mathrm{PhSO}_{2}$, etc. solvent $=\mathrm{MeOH}, \mathrm{CH}_{2} \mathrm{Cl}_{2}$, or $\mathrm{CH}_{2} \mathrm{Cl}_{2} / \mathrm{DMSO}$

Scheme 21. Reactions of mixed phosphonium-iodonium ylides 63 .

\subsection{Cycloaddition reactions of iodonium ylides leading to heterocycles}

Iodonium ylides of different structural types have been used in various heterocyclization reactions under transition metal free conditions or in the presence of metal catalysts. Liang and co-workers have developed a metal-free approach to synthesis of indolines from $\mathrm{N}$-(orthochloromethyl)aryl amides and iodonium ylides. ${ }^{97}$ In particular, $N$-[2(chloromethyl)phenyl]tosylamides 66 react with iodonium ylides 67 at room temperature to afford indolines 68 in moderate yields (Scheme 22). The mechanism of these reactions involves the initial conversion of $\mathrm{N}$-[2-(chloromethyl)phenyl]tosylamides into the aza-o-quinodimethane intermediate under basic conditions, followed by Michael addition and N-alkylation with iodonium ylide to generate indoline by loss of iodobenzene. ${ }^{97}$ 


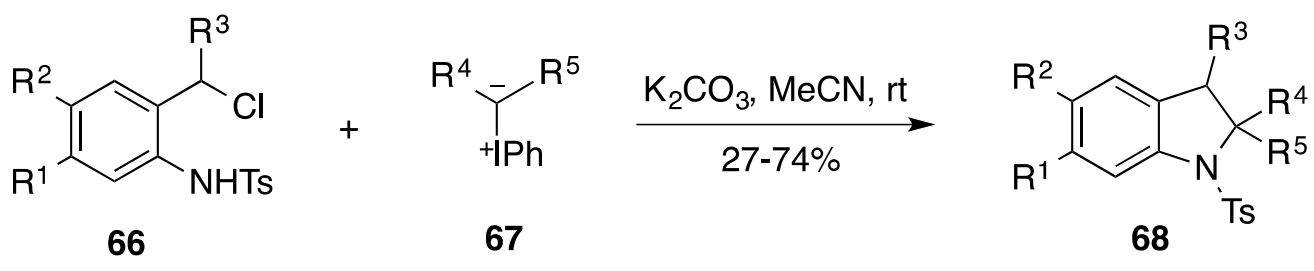

$$
\begin{aligned}
& \mathrm{R}^{1} \text { and } \mathrm{R}^{2}=\mathrm{H}, \mathrm{Cl}, \mathrm{OMe} \\
& \mathrm{R}^{3}=\mathrm{H}, \mathrm{Me} \\
& \mathrm{R}^{4} \text { and } \mathrm{R}^{5}=\mathrm{RC}(\mathrm{O}), \mathrm{RCO}_{2}, \mathrm{CN} \text {, etc. }
\end{aligned}
$$

Scheme 22. Synthesis of indolines from $N$-(ortho-chloromethyl)aryl amides and iodonium ylides.

Liang, Li and co-workers have also reported a mild and general synthesis of benzofurans by cycloaddition of arynes with iodonium ylides. ${ }^{98}$ The aryne intermediates, generated from 2silylaryltriflates 69 in the presence of $\mathrm{CsF}$, undergo the cycloaddition reaction with iodonium ylides $\mathbf{7 0}$ at room temperature to afford the corresponding benzofurans $\mathbf{7 1}$ in moderate to good yields (Scheme 23).<smiles>[R7]c1cc([14CH3])c([14CH3])cc1[R7]</smiles>

69

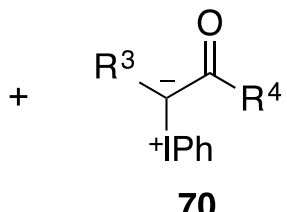

70<smiles>C[C@@H](N(C)C)C(F)(F)F</smiles><smiles>[R7]c1cc2oc([R])c([R3])c2cc1[R7]</smiles>

71

$$
\begin{aligned}
& \mathrm{R}^{1} \text { and } \mathrm{R}^{2}=\mathrm{H}, \text { alkyl, aryl } \\
& \mathrm{R}^{3}=\mathrm{RC}(\mathrm{O}), \mathrm{RCO}_{2}, \mathrm{CN}, \text { etc. } \\
& \mathrm{R}^{4}=\text { alkyl, aryl }
\end{aligned}
$$

Scheme 23. Synthesis of benzofurans by cycloaddition of arynes with iodonium ylides.

Stabilized $\beta$-dicarbonyl iodonium ylides $\mathbf{7 2}$ react with isocyanates $\mathbf{7 3}$ under mild conditions to afford substituted oxazolin-2-ones 74 in moderate yields (Scheme 24). ${ }^{99}$ It has been suggested that this reaction proceeds via carbenoid intermediates, as supported by isolation of the products of carbene dimerization from the reaction mixture.<smiles>[R]C(=O)C(C(=O)OCC)[In](I)c1ccccc1</smiles>

72 $+\quad \operatorname{Ar}-\mathrm{N}=\mathrm{C}=\mathrm{O}$

73

73

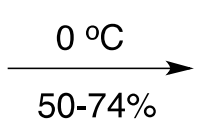<smiles>[R]c1oc(=O)n([12Cl])c1C(=O)OCC</smiles>

$$
\mathrm{R}=\text { Me or OEt; } \mathrm{Ar}=2,4-\mathrm{Cl}_{2} \mathrm{C}_{6} \mathrm{H}_{3}
$$

Scheme 24. Synthesis of oxazolin-2-ones from isocyanates and iodonium ylides. 
The cyclic, dimedone-derived phenyliodonium ylide $\mathbf{7 5}$ serves as an excellent carbenoid precursor useful for synthesis of various heterocycles. Under catalytic, thermal, or photochemical conditions, ylide 75 can transfer the carbenoid moiety to a suitable acceptor resulting in the synthesis of five-membered heterocycles as outlined in Scheme 25. Cycloadditions are typically observed in the reactions of ylide $\mathbf{7 5}$ with acetylenes, ${ }^{100,101}$ alkenes, ${ }^{70,102,103}$ aldehydes, ${ }^{104}$ ketenes, ${ }^{105}$ nitriles, ${ }^{100,106}$ isocyanates, ${ }^{105,107}$ isothiocyanates, ${ }^{108,109}$ and dienes. ${ }^{78,110}$
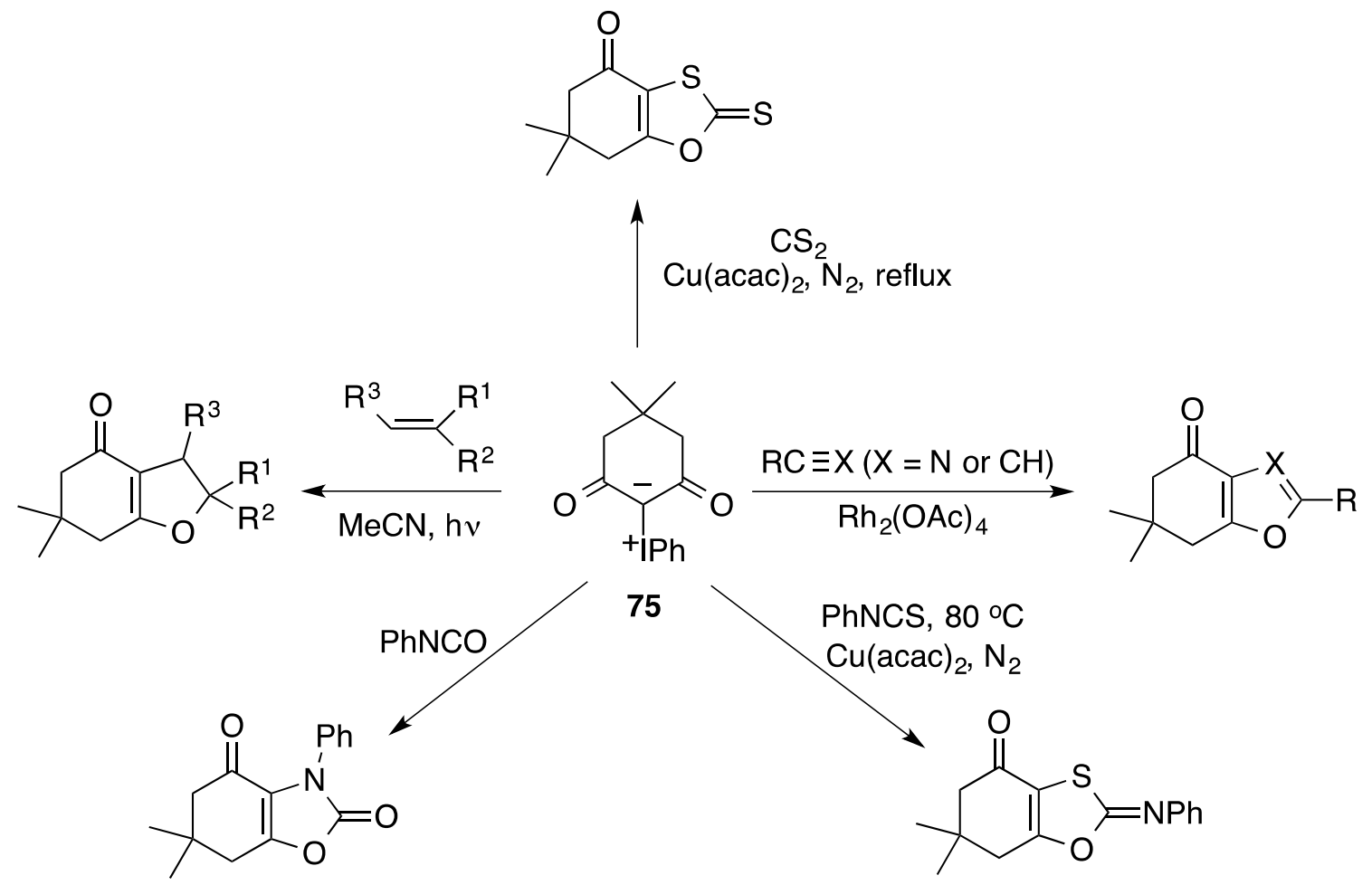

Scheme 25. Synthesis of heterocycles using dimedone-derived phenyliodonium ylide $\mathbf{7 5}$.

A modified, $o$-alkoxy-substituted ylide 76, has an improved solubility in nonpolar solvents, such as aromatic hydrocarbons, and has a generally higher reactivity compared to ylide 75. ${ }^{32}$ Ylide 76 is a useful reagent for the preparation of oxazole derivatives $\mathbf{7 8}$ in the reaction with carbodiimides 77 under homogeneous conditions in the presence of $\mathrm{Rh}$ (II) or $\mathrm{Cu}$ (II) catalysts (Scheme 26). ${ }^{32}$ 


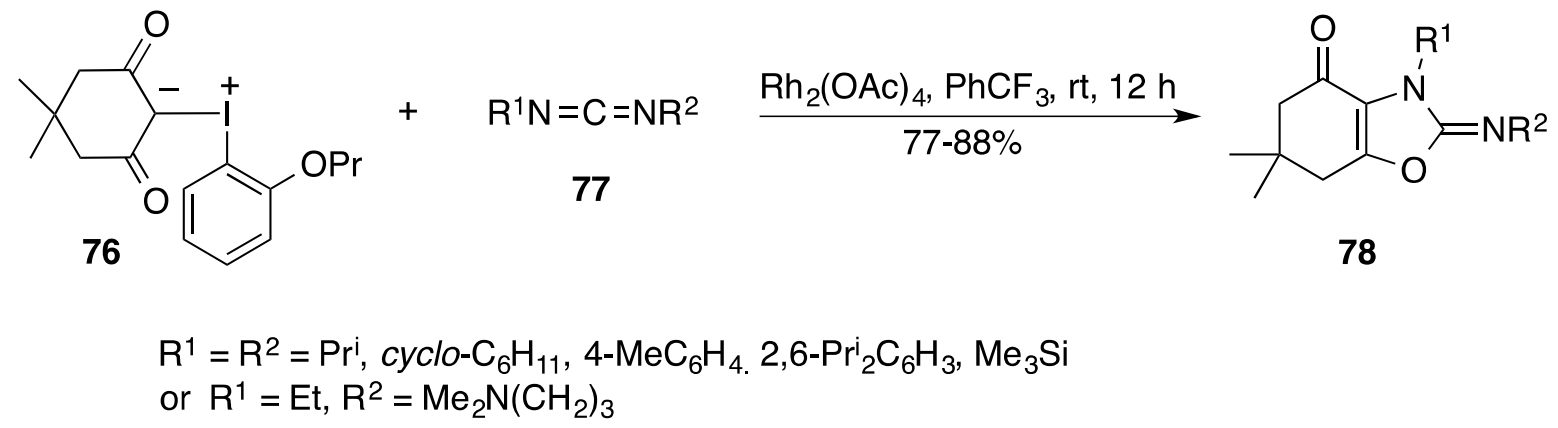

Scheme 26. Synthesis of oxazole derivatives using stabilized phenyliodonium ylide $\mathbf{7 6}$.

Zefirov, Matveeva, and co-workers have demonstrated the utility of mixed phosphoniumiodonium ylides as reagents for the synthesis of various heterocyclic systems such as: substituted oxazoles, ${ }^{92,111}$ phosphonium-substituted furans ${ }^{46}$ substituted phosphinolines, ${ }^{46,91,93,94}$ and annelated phosphorus-containing heterocycles. ${ }^{112-115}$ All these cycloadditions proceed under photochemical conditions. In particular, irradiation of mixed phosphonium iodonium ylides 27 in a nitrile solution with a mercury light source $(254 \mathrm{~nm})$ affords the corresponding oxazole derivatives 79 in moderate yields (Scheme 27). ${ }^{92,116}$

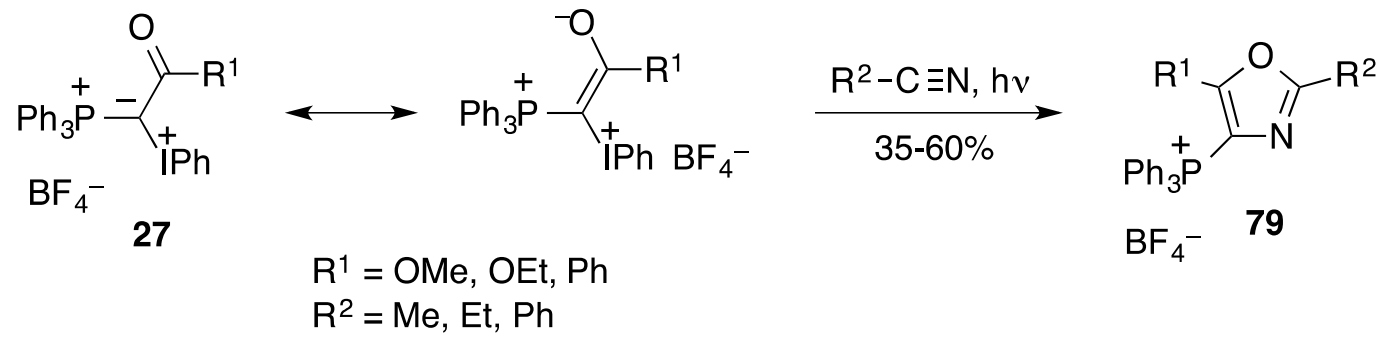

Scheme 27. Synthesis of phosphonium-substituted oxazoles by cycloaddition reactions of mixed phosphonium-iodonium ylides.

The reactions of heteroaryl-substituted (in the phosphonium part) phosphonium-iodonium ylides 80 with alkynes afford either furyl annelated phosphinolines $\mathbf{8 1}$ or phosphonium substituted furans $\mathbf{8 2}$ depending on the nature of the substituent $\mathrm{R}$ in the alkyne (Scheme 28). ${ }^{46,117}$ The authors proposed a mechanism involving the initial elimination of $\mathrm{PhI}$ upon UVirradiation with the formation of an electrophilic intermediate, which interacts with the alkyne to give the corresponding products of cationic cyclization. 


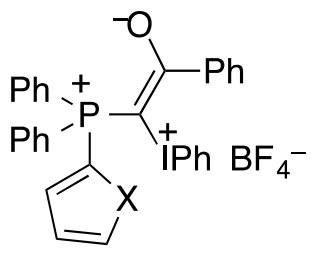

80

$\mathrm{X}=\mathrm{O}$ or $\mathrm{S}$

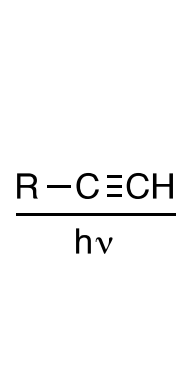

$\underset{40-70 \%}{\stackrel{2}{\text { 9-phenanthryl }}}$<smiles></smiles>

81

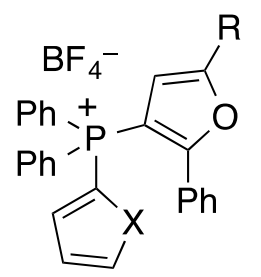

82

Scheme 28. Reactions of heteroaryl-substituted phosphonium-iodonium ylides $\mathbf{8 0}$ with alkynes.

\subsection{Introduction of fluorine using iodonium ylides}

Iodonium ylides have recently attracted some interest as efficient precursors for nucleophilic fluorination in Positron Emission Tomography (PET). ${ }^{118-121}$ Iodonium ylides have an advantage over diaryliodonium salts as the selective PET precursors. Due to the carbanionic character of the ylidic carbon, the attack of an external nucleophile in principle should be directed exclusively toward the aromatic ring of the Ar group of an aryliodonium ylide. However, it was previously demonstrated that the reaction of various organic and inorganic acids with phenyliodonium ylides leads to nucleophilic substitution of the iodobenzene substituent by the anion. ${ }^{122,123}$ Gondo and Kitamura have recently reported that the reaction of iodonium ylides $\mathbf{8 3}$ derived from 1phenylbutan-1,3-dione, ethyl benzoylacetate, and ethyl $p$-nitrobenzoylacetate with $\mathrm{Et}_{3} \mathrm{~N} \cdot 3 \mathrm{HF}$ gave the corresponding fluorinated products 84 in low yields (Scheme 29). ${ }^{124}$ These products are formed through the C-protonation of the ylide, followed by displacement of the PhI by the fluoride ion.<smiles>[R]C(=O)C(=[I+][PH2+])C([R])=O</smiles>

83

$\mathrm{R}^{1}=\mathrm{Ph}$ or $4-\mathrm{NO}_{2} \mathrm{C}_{6} \mathrm{H}_{4}$ $\mathrm{R}^{2}=\mathrm{CH}_{3}$ or OEt

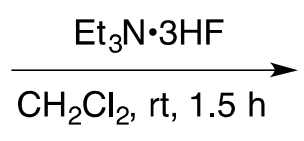<smiles>[R]C(=O)C(F)C([R])=O</smiles>

84

$17-34 \%$

Scheme 29. Reactions of iodonium ylides with $\mathrm{Et}_{3} \mathrm{~N} \cdot 3 \mathrm{HF}$. 
Stuart and co-workers have investigated a similar fluorination of the stable iodonium ylide 85 with $\mathrm{Et}_{3} \mathrm{~N} \cdot 3 \mathrm{HF}$ resulting in the formation of monofluorinated product 86 in $64 \%$ isolated yield along with a small amount of the difluorinated product 87 (Scheme 30 ). ${ }^{33}$<smiles>CC(C)(O)c1ccccc1[I+]C(C(=O)c1ccccc1)C(=O)c1ccccc1</smiles>

85
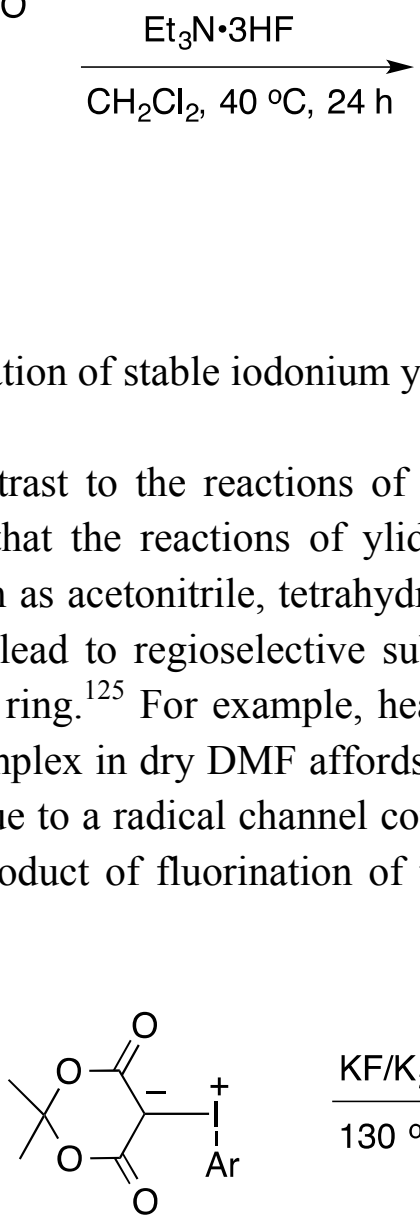

88

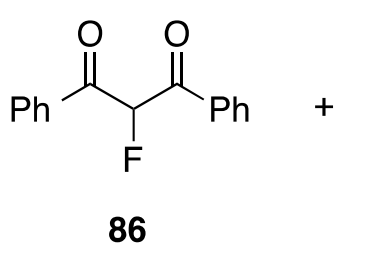

$64 \%$<smiles>O=C(c1ccccc1)C(F)(F)C(=O)c1ccccc1</smiles>

87

$9 \%$

Scheme 30. Fluorination of stable iodonium ylide 85 with $\mathrm{Et}_{3} \mathrm{~N} \cdot 3 \mathrm{HF}$.

In sharp contrast to the reactions of aryliodonium ylides with acids, Satyamurthy and Barrio have found that the reactions of ylides with nucleophiles $\left(\mathrm{F}^{-}, \mathrm{Cl}^{-}, \mathrm{Br}^{-}\right.$, etc. $)$in polar aprotic solvents such as acetonitrile, tetrahydrofuran, dimethylsulfoxide, dimethylacetamide and dimethylformamide lead to regioselective substitution of the nucleophile on the aromatic ring instead of the dione ring. ${ }^{125}$ For example, heating of phenyliodonium ylides $\mathbf{8 8}$ with dried KFKryptofix $\left(\mathrm{K}_{222}\right)$ complex in dry DMF affords fluoroarenes $\mathbf{8 9}$ as main product and hydrocarbon 90 as a byproduct due to a radical channel competing with the nucleophilic substitution reaction (Scheme 31). No product of fluorination of the $\beta$-dicarbonyl moiety has been detected in this reaction. $^{125}$

$$
\begin{aligned}
\mathrm{Ar}= & \mathrm{Ph}, 4-\mathrm{MeC}_{6} \mathrm{H}_{4}, 2,4,6-\mathrm{Me}_{3} \mathrm{C}_{6} \mathrm{H}_{2}, 2-\mathrm{MeOC}_{6} \mathrm{H}_{4}, \\
& \text { 3-MeOC } \mathrm{Me}_{4}, 4-\mathrm{MeOC}_{6} \mathrm{H}_{4}, 4-\mathrm{BrC}_{6} \mathrm{H}_{4}
\end{aligned}
$$

Scheme 31. Reaction of iodonium ylides with fluoride anion in DMF.

This approach has been employed for the radiofluorination of protected L-DOPA derivatives. ${ }^{125}$ A radiochemically pure amino acid L-6- $\left[{ }^{18} \mathrm{~F}\right]$ fluoroDOPA 91 has been produced in amounts usable for human PET studies as shown in Scheme 32. The fluorine-18 labeled LDOPA is a useful PET imaging agent for mapping dopamine related brain disorders and is the PET biomarker of choice for the diagnosis of Parkinson's disease. 

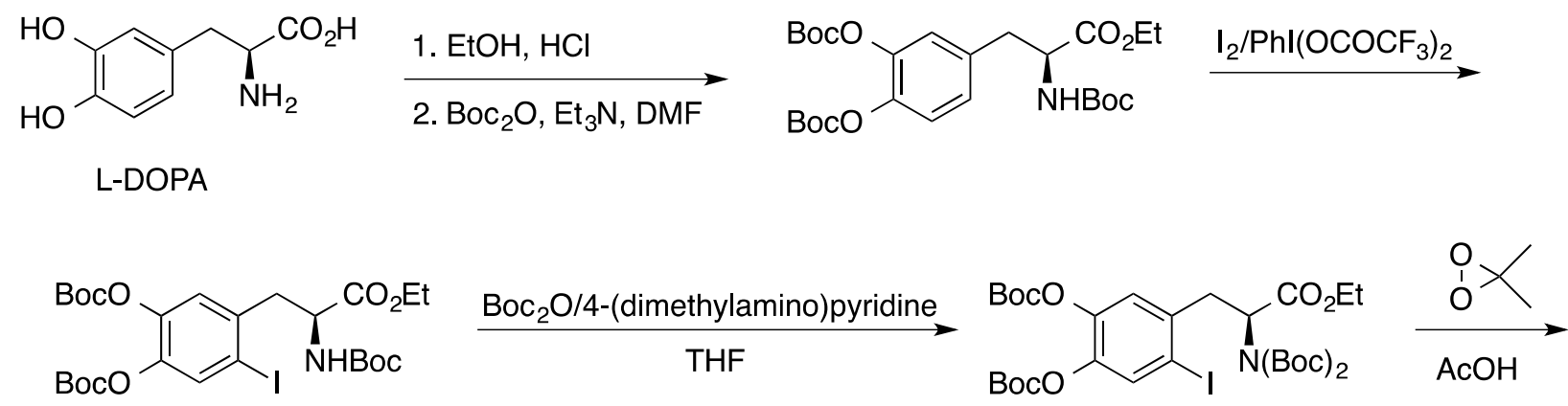

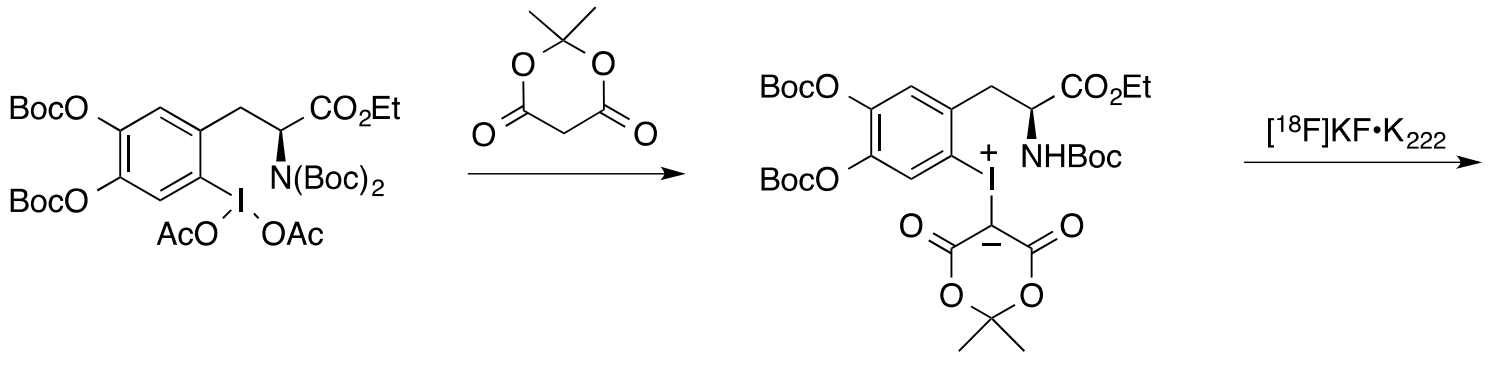<smiles>CCOC(=O)C(Cc1cc(OC(C)(C)C)c(OC(C)(C)C)cc1F)NC(=O)OC(C)(C)C</smiles>

$\mathrm{Boc}=t-\mathrm{BuOCO}$

91

Scheme 32. Radiosynthesis of L-6- $\left[{ }^{18} \mathrm{~F}\right]$ fluoroDOPA 91.<smiles>N#Cc1cc(C#Cc2ccccn2)cc([I+]C2C(=O)OC3(CCCC3)OC2=O)c1</smiles>

92<smiles>[NH3+]Cc1ccc([I-]C2C(=O)OC3(CCCC3)OC2=O)cc1</smiles>

94
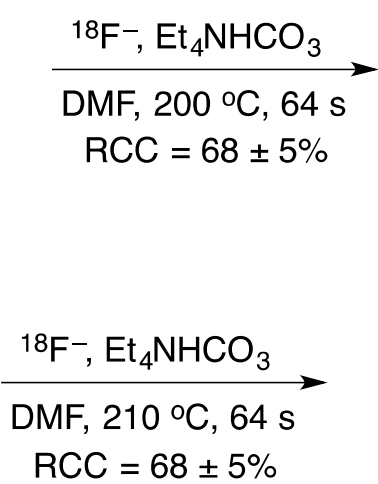

$\mathrm{RCC}=68 \pm 5 \%$<smiles>N#Cc1cc(F)cc(C#Cc2ccccn2)c1</smiles>

93<smiles>NCc1ccc(F)cc1</smiles>

95

Scheme 33. Radiosynthesis of ([ $\left[{ }^{18} \mathrm{~F}\right] \mathrm{FPEB} 91$. 
Vasdev, Liang, and co-workers have demonstrated that the spirocyclic hypervalent iodine(III) ylides can serve as synthetically versatile precursors for efficient radiolabelling of a diverse range of non-activated (hetero)arenes, highly functionalized small molecules, building blocks, and radiopharmaceuticals from $\left[{ }^{18} \mathrm{~F}\right]$ fluoride ion. ${ }^{126,127}$ In particular, the reactions of ylides 92 and 94 under continuous-flow microfluidic condition offers automated synthetic procedure for the preparation of a radiopharmaceutical, 3- $\left[{ }^{18} \mathrm{~F}\right]$ fluoro-5-[(pyridin-3yl)ethynyl $]$ benzonitrile ([$\left.\left[{ }^{18} \mathrm{~F}\right] \mathrm{FPEB}\right) \mathbf{9 3}$, and a routinely used building block for clickradiochemistry, 4- $\left[{ }^{18}\right.$ F]fluorobenzyl azide 95 in $68 \%$ radiochemical conversion (RCC) (Scheme $33)$.

\subsection{Thiotrifluoromethylation using iodonium ylides}

In 2013, Shibata and co-workers have introduced a novel electrophilic-type trifluoromethylthiolation reagent, trifluoromethanesulfonyl iodonium ylide 96, which can react with various nucleophiles to afford $\mathrm{CF}_{3} \mathrm{~S}$-substituted products 97 (Scheme 34). ${ }^{128}$ These reactions have a complex mechanism involving in situ reduction of the trifluoromethanesulfonyl group in the presence of a copper catalyst to give the trifluoromethylthio group. The key steps of this mechanism are shown in Scheme 34.
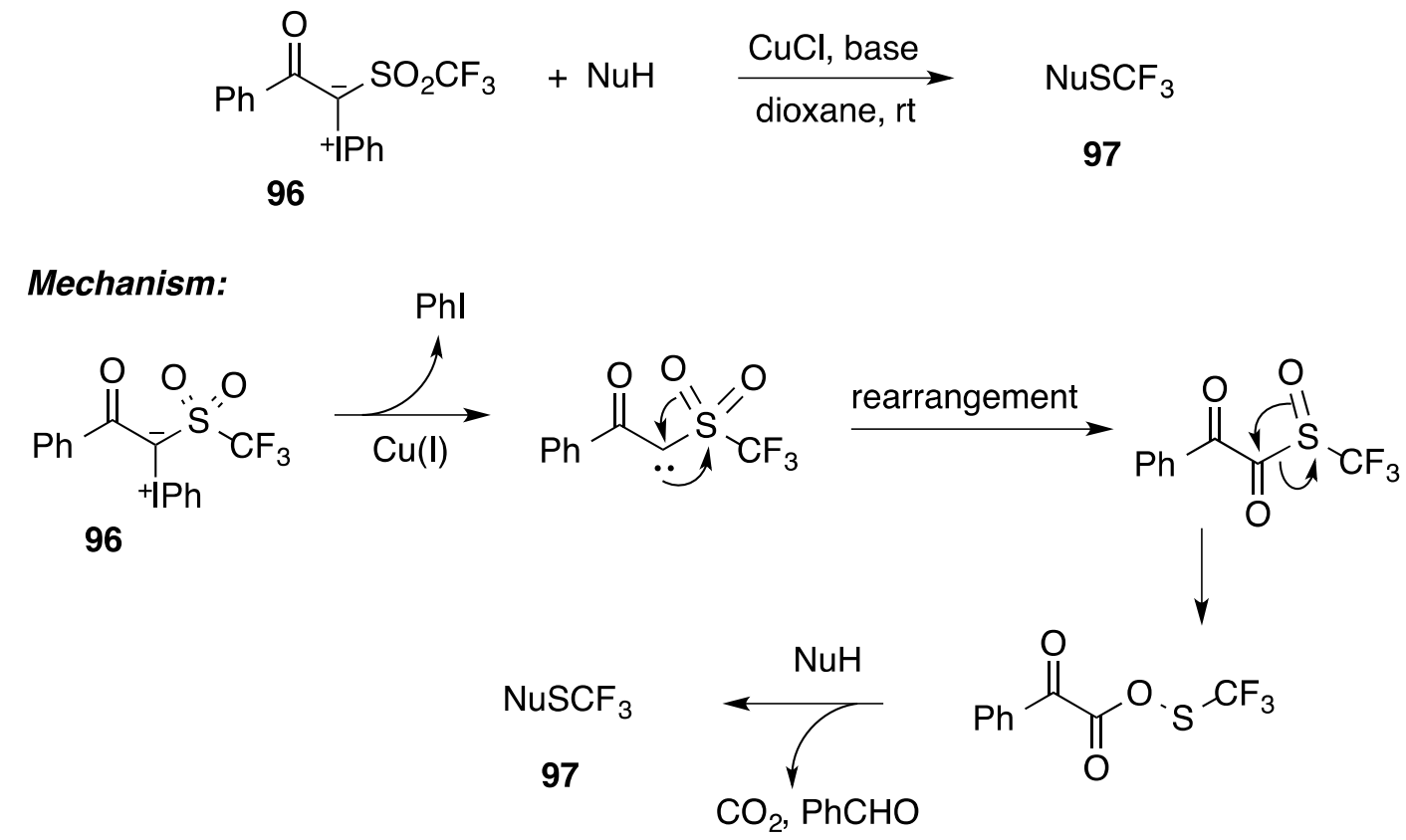

Scheme 34. Copper-catalyzed trifluoromethylthiolations by iodonium ylide 96.

In the original work, Shibata and co-workers have reported thiotrifluoromethylation of enamines, $\beta$-keto esters, and indoles using iodonium ylide 96. ${ }^{126}$ For example, indoles 98 smoothly react with reagent 96 affording trifluoromethylthiolated products 99 in generally high yields (Scheme 35). 
<smiles>[R]c1ccc2c(c1)cc([R])n2[R]</smiles>

98
96, $\mathrm{CuCl}(20 \mathrm{~mol} \%)$

$\mathrm{PhNMe}_{2}$, dioxane, rt

$32-84 \%$<smiles>[R]c1ccc2[nH]c([R])c(C(F)(F)F)c2c1</smiles>

$R^{3}$

99

Scheme 35. Thiotrifluoromethylation of indoles.

In a series of more recent publications, reagent 96 has been used for thiotrifluoromethylation of various other nucleophilic substrates, such as: allyl alcohols and boronic acids, ${ }^{129}$ arylamines, ${ }^{130}$ allylsilanes and silyl enol ethers, ${ }^{131}$ and pyrroles. ${ }^{132}$ Several examples of thiotrifluoromethylation reactions of these substrates are shown in Scheme 36.
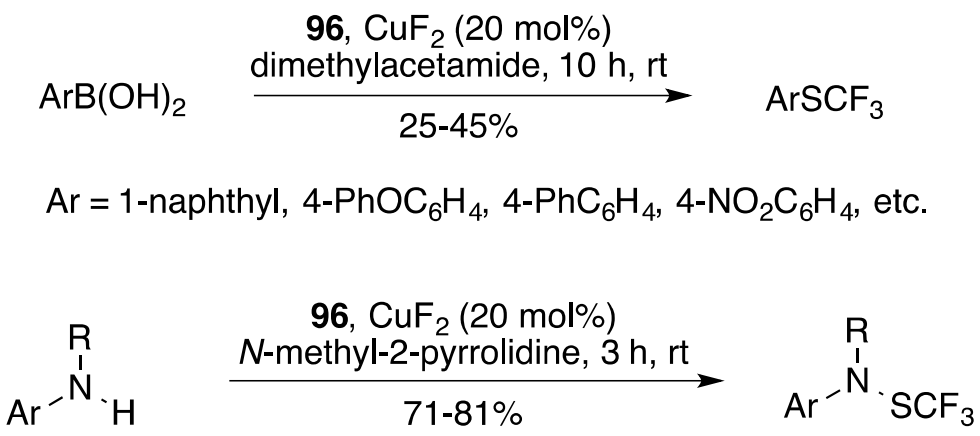

$\mathrm{R}=$ aryl, benzyl

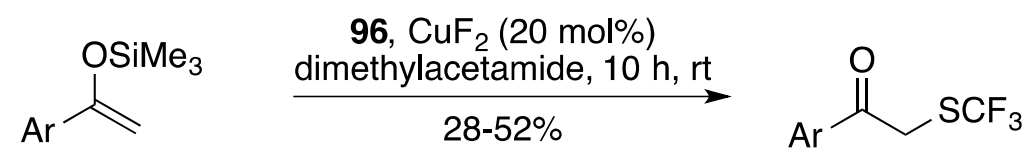

$\mathrm{Ar}=\mathrm{Ph}, 2-$ naphthyl, 2-MeOC $\mathrm{H}_{4} \mathrm{H}_{4}, 3-\mathrm{MeOC}_{6} \mathrm{H}_{4}$, 4- $\mathrm{MeOC}_{6} \mathrm{H}_{4}, 4-\mathrm{ClC}_{6} \mathrm{H}_{4}, 3-\mathrm{FC}_{6} \mathrm{H}_{4}$, etc.<smiles>[R]c1ccc[nH]1</smiles>

96, $\mathrm{CuF}_{2}(20 \mathrm{~mol} \%)$

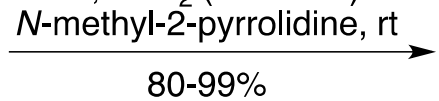<smiles>[R]c1ccc([As](F)(F)F)[nH]1</smiles>

$\mathrm{R}=\mathrm{alkyl}$, aryl, alkenyl

Scheme 36. Thiotrifluoromethylation of organic substrates. 


\section{Conclusions}

This review demonstrates that iodonium ylides of different structural types are becoming increasingly popular reagents in organic synthesis. Iodonium ylides are widely used as efficient carbene precursors, especially useful as reagents for cyclopropanation of alkenes and preparation of heterocyclic compounds. Recently iodonium ylides have been utilized as efficient reagents in the thiotrifluoromethylation and nucleophilic fluorination reactions, which find practical application in Positron Emission Tomography. We anticipate that this synthetically important area of hypervalent iodine chemistry will continue to attract significant research activity in the future.

\section{Acknowledgements}

M.S.Y. is thankful to the Ministry of Education and Science of Russian Federation (project 'Science' No. 4.2569.2014/K). Our work was also supported by a research grant from the National Science Foundation (CHE-1262479).

\section{References}

1. Yoshimura, A.; Zhdankin, V. V. Chem. Rev. 2016, 116, 3328-3435. http://dx.doi.org/10.1021/acs.chemrev.5b00547

2. Kaiho, T.; Editor Iodine Chemistry And Applications; John Wiley \& Sons, Inc.: Chichester (UK), 2015.

3. Zhdankin, V. V. Hypervalent Iodine Chemistry: Preparation, Structure and Synthetic Application of Polyvalent Iodine Compounds; John Wiley \& Sons Ltd: Chichester (UK), 2014.

4. Yoshimura, A.; Yusubov, M. S.; Zhdankin, V. V. Org. Biomol. Chem. 2016, 14, 47714781.

http://dx.doi.org/10.1039/C6OB00773B

5. Yusubov, M. S.; Zhdankin, V. V. Mendeleev Commun. 2010, 20, 185-191.

http://dx.doi.org/10.1016/j.mencom.2010.06.001

6. Zhdankin, V. V. Adv. Heterocycl. Chem. 2015, 115, 1-91.

http://dx.doi.org/10.1016/bs.aihch.2015.03.003

7. Zhdankin, V. V. Adv. Heterocycl. Chem. 2016, 116, 57-79.

http://dx.doi.org/10.1016/bs.aihch.2015.11.001

8. Yusubov, M. S.; Zhdankin, V. V. Resource-Efficient Technologies 2015, 1, 49-67. http://dx.doi.org/10.1016/j.reffit.2015.06.001

9. Yusubov, M. S.; Zhdankin, V. V. Curr. Org. Synth. 2012, 9, 247-272. http://dx.doi.org/10.2174/157017912799829021 
10. Zhdankin, V. V. J. Org. Chem. 2011, 76, 1185-1197.

http://dx.doi.org/10.1021/jo1024738

11. Ladziata, U.; Zhdankin, V. V. Arkivoc 2006, (ix), 26-58.

http://dx.doi.org/10.3998/ark.5550190.0007.903

12. Zhdankin, V. V. Arkivoc 2009, (i), 1-62. http://dx.doi.org/10.3998/ark.5550190.0010.101

13. Yusubov, M. S.; Maskaev, A. V.; Zhdankin, V. V. Arkivoc 2011, (i), 370-409. http://dx.doi.org/10.3998/ark.5550190.0012.107

14. Kirmse, W. Eur. J. Org. Chem. 2005, 237-260.

http://dx.doi.org/10.1002/ejoc.200400415

15. Muller, P.; Allenbach, Y. F.; Chappellet, S.; Ghanem, A. Synthesis 2006, 1689-1696. http://dx.doi.org/10.1055/s-2006-926452

16. Muller, P. Acc. Chem. Res. 2004, 37, 243-251. http://dx.doi.org/10.1021/ar0202619

17. Malamidou-Xenikaki, E.; Spyroudis, S. Synlett 2008, 2725-2740.

18. Neilands, O. Chem. Heterocycl. Compd. (Engl. Transl.) 2003, 39, 1555-1569.

19. Gudriniece, E.; Neiland, O.; Vanags, G. Zh. Obshch. Khim. 1957, 27, 2737-2740.

20. Hadjiarapoglou, L.; Spyroudis, S.; Varvoglis, A. J. Am. Chem. Soc. 1985, 107, 7178-7189. http://dx.doi.org/10.1021/ja00310a072

21. Hatjiarapoglou, L.; Varvoglis, A.; Alcock, N. W.; Pike, G. A. J. Chem. Soc., Perkin Trans. 1 1988, 2839-2846.

http://dx.doi.org/10.1039/p19880002839

22. Goudreau, S. R.; Marcoux, D.; Charette, A. B. J. Org. Chem. 2009, 74, 470-473. http://dx.doi.org/10.1021/jo802208q

23. Cardinale, J.; Ermert, J. Tetrahedron Lett. 2013, 54, 2067-2069. http://dx.doi.org/10.1016/j.tetlet.2013.02.018

24. Zhu, S.-Z. Heteroatom Chem. 1994, 5, 9-18. http://dx.doi.org/10.1002/hc.520050104

25. Hackenberg, J.; Hanack, M. J. Chem. Soc., Chem. Commun. 1991, 470-471. http://dx.doi.org/10.1039/c39910000470

26. Zhu, S.; Chen, Q. J. Chem. Soc., Chem. Commun. 1990, 1459-1460. http://dx.doi.org/10.1039/c39900001459

27. Zhu, S.; Chen, Q.; Kuang, W. J. Fluorine Chem. 1993, 60, 39-42. http://dx.doi.org/10.1016/S0022-1139(00)82192-2

28. Goudreau, S. R.; Marcoux, D.; Charette, A. B.; Hughes, D. Org. Synth. 2010, 87, 115-125. http://dx.doi.org/10.15227/orgsyn.087.0115

29. Yu, J.; Liu, S.-S.; Cui, J.; Hou, X.-S.; Zhang, C. Org. Lett. 2012, 14, 832-835. http://dx.doi.org/10.1021/ol203358f

30. Zhdankin, V. V.; Protasiewicz, J. D. Coord. Chem. Rev. 2014, 275, 54-62. http://dx.doi.org/10.1016/j.ccr.2014.04.007 
31. Zhu, C.; Yoshimura, A.; Ji, L.; Wei, Y.; Nemykin, V. N.; Zhdankin, V. V. Org. Lett. 2012, 14, 3170-3173.

http://dx.doi.org/10.1021/ol301268j

32. Zhu, C.; Yoshimura, A.; Solntsev, P.; Ji, L.; Wei, Y.; Nemykin, V. N.; Zhdankin, V. V. Chem. Commun. 2012, 48, 10108-10110.

http://dx.doi.org/10.1039/c2cc35708a

33. Geary, G. C.; Hope, E. G.; Singh, K.; Stuart, A. M. RSC Adv. 2015, 5, 16501-16506. http://dx.doi.org/10.1039/C4RA15733H

34. Yang, R.; Dai, L.; Chen, C. J. Chem. Soc., Chem. Commun. 1992, 1487-1488. http://dx.doi.org/10.1039/C39920001487

35. Maletina, I. I.; Orda, V. V.; Yagupolskii, Y. L. J. Fluor. Chem. 1995, 70, 85-88. http://dx.doi.org/10.1016/0022-1139(94)03091-D

36. Ochiai, M.; Tada, N.; Okada, T.; Sota, A.; Miyamoto, K. J. Am. Chem. Soc. 2008, 130, 2118-2119. http://dx.doi.org/10.1021/ja074624h

37. Ochiai, M.; Okada, T.; Tada, N.; Yoshimura, A. Org. Lett. 2008, 10, 1425-1428. http://dx.doi.org/10.1021/ol800211x

38. Kokil, P. B.; Nair, P. M. Tetrahedron Lett. 1977, 4113-4116. http://dx.doi.org/10.1016/S0040-4039(01)83441-9

39. Neilands, O.; Vanags, G. Dokl. Akad. Nauk SSSR 1964, 159, 373-376.

40. Moriarty, R. M.; Prakash, I.; Prakash, O.; Freeman, W. A. J. Am. Chem. Soc. 1984, 106, 6082-6084.

http://dx.doi.org/10.1021/ja00332a057

41. Weiss, R.; Seubert, J. Angew. Chem., Int. Ed. 1994, 33, 891-893. http://dx.doi.org/10.1002/anie.199408911

42. Zhdankin, V. V.; Maydanovych, O.; Herschbach, J.; Bruno, J.; Matveeva, E. D.; Zefirov, N. S. Tetrahedron Lett. 2002, 43, 2359-2361. http://dx.doi.org/10.1016/S0040-4039(02)00275-7

43. Matveeva, E. D.; Podrugina, T. A.; Grishin, Y. K.; Tkachev, V. V.; Zhdankin, V. V.; Aldoshin, S. M.; Zefirov, N. S. Russ. J. Org. Chem. 2003, 39, 536-541. http://dx.doi.org/10.1023/A:1026011902365

44. Zhdankin, V. V.; Maydanovych, O.; Herschbach, J.; Bruno, J.; Matveeva, E. D.; Zefirov, N. S. J. Org. Chem. 2003, 68, 1018-1023.

http://dx.doi.org/10.1021/jo026604y

45. Huang, Z.-Z.; Yu, X.-C.; Huang, X. Tetrahedron Lett. 2002, 43, 6823-6825. http://dx.doi.org/10.1016/S0040-4039(02)01503-4

46. Matveeva, E. D.; Podrugina, T. A.; Taranova, M. A.; Ivanova, A. M.; Gleiter, R.; Zefirov, N. S. J. Org. Chem. 2012, 77, 5770-5774.

http://dx.doi.org/10.1021/jo3008836

47. Ochiai, M.; Kitagawa, Y. Tetrahedron Lett. 1998, 39, 5569-5570. 
http://dx.doi.org/10.1016/S0040-4039(98)01122-8

48. Ochiai, M.; Kitagawa, Y. J. Org. Chem. 1999, 64, 3181-3189.

http://dx.doi.org/10.1021/jo982346m

49. Ochiai, M.; Kitagawa, Y.; Yamamoto, S. J. Am. Chem. Soc. 1997, 119, 11598-11604. http://dx.doi.org/10.1021/ja971688r

50. Ochiai, M.; Tuchimoto, Y.; Higashiura, N. Org. Lett. 2004, 6, 1505-1508.

http://dx.doi.org/10.1021/o10495669

51. Ochiai, M.; Nishitani, J.; Nishi, Y. J. Org. Chem. 2002, 67, 4407-4413. http://dx.doi.org/10.1021/jo0107711

52. Miyamoto, K.; Suzuki, M.; Suefuji, T.; Ochiai, M. Eur. J. Org. Chem. 2013, 3662-3666. http://dx.doi.org/10.1002/ejoc.201300413

53. Alcock, N. W.; Bozopoulos, A. P.; Hatzigrigoriou, E.; Varvoglis, A. Acta Crystallogr., Sect. C: Cryst. Struct. Commun. 1990, C46, 1300-1303.

54. Huang, Z.; Yu, X.; Huang, X. J. Org. Chem. 2002, 67, 8261-8264. http://dx.doi.org/10.1021/jo026077i

55. Nishimura, T.; Iwasaki, H.; Takahashi, M.; Takeda, M. J. Radioanal. Nucl. Chem. 2003, 255, 499-502.

http://dx.doi.org/10.1023/A:1022576230920

56. Ivanov, A. S.; Popov, I. A.; Boldyrev, A. I.; Zhdankin, V. V. Angew. Chem., Int. Ed. 2014, 53, 9617-9621.

http://dx.doi.org/10.1002/anie.201405142

57. Batsila, C.; Gogonas, E. P.; Kostakis, G.; Hadjiarapoglou, L. P. Org. Lett. 2003, 5, 15111514.

http://dx.doi.org/10.1021/o10343008

58. Telu, S.; Durmus, S.; Koser, G. F. Tetrahedron Lett. 2007, 48, 1863-1866.

http://dx.doi.org/10.1016/j.tetlet.2006.12.132

59. Muller, P.; Bolea, C. Molecules 2001, 6, 258-266.

http://dx.doi.org/10.3390/60300258

60. Muller, P.; Bolea, C. Helv. Chim. Acta 2002, 85, 483-494.

http://dx.doi.org/10.1002/1522-2675(200202)85:2<483::AID-HLCA483>3.0.CO;2-Q

61. Muller, P.; Tohill, S. Tetrahedron 2000, 56, 1725-1731.

http://dx.doi.org/10.1016/S0040-4020(00)00076-4

62. Moriarty, R. M.; Prakash, O.; Vaid, R. K.; Zhao, L. J. Am. Chem. Soc. 1989, 111, 64436444.

http://dx.doi.org/10.1021/ja00198a078

63. Camacho, M. B.; Clark, A. E.; Liebrecht, T. A.; DeLuca, J. P. J. Am. Chem. Soc. 2000, $122,5210-5211$.

http://dx.doi.org/10.1021/ja000334o

64. Ghanem, A.; Lacrampe, F.; Schurig, V. Helv. Chim. Acta 2005, 88, 216-239.

http://dx.doi.org/10.1002/hlca.200590003 
65. Georgakopoulou, G.; Kalogiros, C.; Hadjiarapoglou, L. P. Synlett 2001, 1843-1846. http://dx.doi.org/10.1055/s-2001-18750

66. Batsila, C.; Kostakis, G.; Hadjiarapoglou, L. P. Tetrahedron Lett. 2002, 43, 5997-6000. http://dx.doi.org/10.1016/S0040-4039(02)01260-1

67. Ghanem, A.; Aboul-Enein Hassan, Y.; Muller, P. Chirality 2005, 17, 44-50. http://dx.doi.org/10.1002/chir.20093

68. Muller, P.; Bolea, C. Helv. Chim. Acta 2001, 84, 1093-1111. http://dx.doi.org/10.1002/1522-2675(20010516)84:5<1093::AID-HLCA1093>3.0.CO;2-T

69. Mueller, P.; Fernandez, D. Helv. Chim. Acta 1995, 78, 947-958. http://dx.doi.org/10.1002/hlca.19950780417

70. Bosnidou, A.-E.; Kalpogiannaki, D.; Karanestora, S.; Nixas, J. A.; Hadjiarapoglou, L. P. J. Org. Chem. 2015, 80, 1279-1283. http://dx.doi.org/10.1021/jo502611x

71. Bonge, H. T.; Hansen, T. Synlett 2007, 55-58.

72. Wurz, R. P.; Charette, A. B. Org. Lett. 2003, 5, 2327-2329. http://dx.doi.org/10.1021/o1034672g

73. Moreau, B.; Charette, A. B. J. Am. Chem. Soc. 2005, 127, 18014-18015. http://dx.doi.org/10.1021/ja0561921

74. Moreau, B.; Alberico, D.; Lindsay, V. N. G.; Charette, A. B. Tetrahedron 2012, 68, 34873496.

http://dx.doi.org/10.1016/j.tet.2011.05.113

75. Bonge, H. T.; Hansen, T. Tetrahedron Lett. 2008, 49, 57-61. http://dx.doi.org/10.1016/j.tetlet.2007.11.021

76. Adam, W.; Gogonas, E. P.; Hadjiarapoglou, L. P. Tetrahedron 2003, 59, 7929-7934. http://dx.doi.org/10.1016/j.tet.2003.07.011

77. Adam, W.; Gogonas, E. P.; Hadjiarapoglou, L. P. Eur. J. Org. Chem. 2003, 1064-1068. http://dx.doi.org/10.1002/ejoc.200390156

78. Lee, Y. R.; Yoon, S. H.; Seo, Y.; Kim, B. S. Synthesis 2004, 2787-2798. http://dx.doi.org/10.1055/s-2004-831257

79. Lee, Y. R.; Yoon, S. H. Synth. Commun. 2006, 36, 1941-1951. http://dx.doi.org/10.1080/00397910600631957

80. Lee, Y. R.; Jung, Y. U. J. Chem. Soc., Perkin Trans. 1 2002, 1309-1313. http://dx.doi.org/10.1039/b111206f

81. Moriarty, R. M.; Tyagi, S.; Ivanov, D.; Constantinescu, M. J. Am. Chem. Soc. 2008, 130, 7564-7565. http://dx.doi.org/10.1021/ja802735f

82. Murphy, G. K.; West, F. G. Org. Lett. 2006, 8, 4359-4361. http://dx.doi.org/10.1021/o10617720

83. Adam, W.; Gogonas, E. P.; Hadjiarapoglou, L. P. J. Org. Chem. 2003, 68, 9155-9158. http://dx.doi.org/10.1021/jo035362e 
84. Adam, W.; Gogonas, E. P.; Hadjiarapoglou, L. P. Synlett 2003, 1165-1169.

85. Adam, W.; Gogonas, E. P.; Nyxas, I. A.; Hadjiarapoglou, L. P. Synthesis 2007, 3211-3218.

86. Adam, W.; Bosio, S. G.; Gogonas, E. P.; Hadjiarapoglou, L. P. Synthesis 2002, 2084-2090. http://dx.doi.org/10.1055/s-2002-34376

87. Moriarty, R. M.; Tyagi, S.; Kinch, M. Tetrahedron 2010, 66, 5801-5810. http://dx.doi.org/10.1016/j.tet.2010.05.005

88. Mueller, P.; Allenbach, Y. F.; Ferri, M.; Bernardinelli, G. ARKIVOC 2003, (vii), 80-95. http://dx.doi.org/10.3998/ark.5550190.0004.709

89. Ho, P. E.; Tao, J.; Murphy, G. K. Eur. J. Org. Chem. 2013, 6540-6544. http://dx.doi.org/10.1002/ejoc.201300954

90. Matveeva, E. D.; Podrugina, T. A.; Grishin, Y. K.; Pavlova, A. S.; Zefirov, N. S. Russ. J. Org. Chem. 2007, 43, 201-206. http://dx.doi.org/10.1134/S107042800702008X

91. Matveeva, E. D.; Podrugina, T. A.; Pavlova, A. S.; Mironov, A. V.; Borisenko, A. A.; Gleiter, R.; Zefirov, N. S. J. Org. Chem. 2009, 74, 9428-9432. http://dx.doi.org/10.1021/jo901984q

92. Matveeva, E. D.; Podrugina, T. A.; Pavlova, A. S.; Mironov, A. V.; Gleiter, R.; Zefirov, N. S. Eur. J. Org. Chem. 2009, 2323-2327. http://dx.doi.org/10.1002/ejoc.200801251

93. Matveeva, E. D.; Podrugina, T. A.; Taranova, M. A.; Borisenko, A. A.; Mironov, A. V.; Gleiter, R.; Zefirov, N. S. J. Org. Chem. 2011, 76, 566-572. http://dx.doi.org/10.1021/jo101993a

94. Matveeva, E. D.; Gleiter, R.; Zefirov, N. S. Russ. Chem. Bull. 2010, 59, 488. http://dx.doi.org/10.1007/s11172-010-0110-7

95. Matveeva, E. D.; Podrugina, T. A.; Pavlova, A. S.; Mironov, A. V.; Zefirov, N. S. Russ. Chem. Bull. 2008, 57, 400-405. http://dx.doi.org/10.1007/s11172-008-0061-4

96. Deng, G. J. Chem. Res. (S) 2002, 558-559.

97. Huang, H.; Yang, Y.; Zhang, X.; Zeng, W.; Liang, Y. Tetrahedron Lett. 2013, 54, 60496052 .

http://dx.doi.org/10.1016/j.tetlet.2013.08.096

98. Huang, X.-C.; Liu, Y.-L.; Liang, Y.; Pi, S.-F.; Wang, F.; Li, J.-H. Org. Lett. 2008, 10, $1525-1528$.

http://dx.doi.org/10.1021/o1800051k

99. Gololobov, Y. G.; Golding, I. R.; Galkina, M. A.; Lokshin, B. V.; Garbuzova, I. A.; Petrovskii, P. V.; Starikova, Z. A.; Averkiev, B. B. Russ. Chem. Bull. 2006, 55, 883-891. http://dx.doi.org/10.1007/s11172-006-0347-3

100. Gogonas, E. P.; Hadjiarapoglou, L. P. Tetrahedron Lett. 2000, 41, 9299-9303. http://dx.doi.org/10.1016/S0040-4039(00)01672-5

101. Sivaraman, M.; Muralidharan, D.; Perumal, P. T. Tetrahedron Lett. 2013, 54, 1507-1509. 
http://dx.doi.org/10.1016/j.tetlet.2012.12.108

102. Kalpogiannaki, D.; Martini, C.-I.; Nikopoulou, A.; Nyxas, J. A.; Pantazi, V.; Hadjiarapoglou, L. P. Tetrahedron 2013, 69, 1566-1575.

http://dx.doi.org/10.1016/j.tet.2012.12.006

103. Paizanos, K.; Charalampou, D.; Kourkoumelis, N.; Kalpogiannaki, D.; Hadjiarapoglou, L.; Spanopoulou, A.; Lazarou, K.; Manos, M. J.; Tasiopoulos, A. J.; Kubicki, M.; Hadjikakou, S. K. Inorg. Chem. 2012, 51, 12248-12259.

http://dx.doi.org/10.1021/ic3014255

104. Tu, X.-C.; Yu, Y.; Tu, M.-S.; Jiang, B.; Li, C.; Tu, S.-J. J. Heterocycl. Chem. 2014, 51, 436-441. http://dx.doi.org/10.1002/jhet.1732

105. Koser, G. F.; Yu, S.-M. J. Org. Chem. 1975, 40, 1166-1169. http://dx.doi.org/10.1021/jo00896a037

106. Asouti, A.; Hadjiarapoglou, L. P. Tetrahedron Lett. 1998, 39, 9073-9076. http://dx.doi.org/10.1016/S0040-4039(98)01997-2

107. Lee, Y. R.; Suk, J. Y.; Kim, B. S. Tetrahedron Lett. 1999, 40, 6603-6607. http://dx.doi.org/10.1016/S0040-4039(99)01317-9

108. Koser, G. F.; Yu, S.-M. J. Org. Chem. 1976, 41, 125-128. http://dx.doi.org/10.1021/jo00863a028

109. Hadjiarapoglou, L. P. Tetrahedron Lett. 1987, 28, 4449-4450. http://dx.doi.org/10.1016/S0040-4039(00)96535-3

110. Pirrung, M. C.; Zhang, J.; Lackey, K.; Sternbach, D. D.; Brown, F. J. Org. Chem. 1995, 60, 2112-2124. http://dx.doi.org/10.1021/jo00112a036

111. Matveeva, E. D.; Podrugina, T. A.; Pavlova, A. S.; Mironov, A. V.; Zefirov, N. S. Russ. Chem. Bull. 2008, 57, 2237-2239. http://dx.doi.org/10.1007/s11172-008-0313-3

112. Matveeva, E. D.; Podrugina, T. A.; Taranova, M. A.; Vinogradov, D. S.; Gleiter, R.; Zefirov, N. S. J. Org. Chem. 2013, 78, 11691-11697. http://dx.doi.org/10.1021/jo401514d

113. Matveeva, E. D.; Podrugina, T. A.; Taranova, M. A.; Melikhova, E. Y.; Gleiter, R.; Zefirov, N. S. Tetrahedron 2013, 69, 7395-7402. http://dx.doi.org/10.1016/j.tet.2013.06.066

114. Matveeva, E. D.; Vinogradov, D. S.; Podrugina, T. A.; Nekipelova, T. D.; Mironov, A. V.; Gleiter, R.; Zefirov, N. S. Eur. J. Org. Chem. 2015, 7324-7333. http://dx.doi.org/10.1002/ejoc.201500876

115. Nekipelova, T. D.; Taranova, M. A.; Matveeva, E. D.; Kuz'min, V. A.; Zefirov, N. S. Kinet. Catal. 2015, 56, 403-411. http://dx.doi.org/10.1134/S0023158415040138 
116. Nekipelova, T. D.; Kuzmin, V. A.; Matveeva, E. D.; Gleiter, R.; Zefirov, N. S. J. Phys. Org. Chem. 2013, 26, 137-143.

http://dx.doi.org/10.1002/poc.2972

117. Nekipelova, T. D.; Taranova, M. A.; Matveeva, E. D.; Podrugina, T. A.; Kuzmin, V. A.; Zefirov, N. S. Dokl. Chem. 2012, 447, 262-265. http://dx.doi.org/10.1134/S0012500812110092

118. Yusubov, M. S.; Svitich, D. Y.; Larkina, M. S.; Zhdankin, V. V. Arkivoc 2013, (i), 364395.

119. Preshlock, S.; Tredwell, M.; Gouverneur, V. Chem. Rev. 2016, 116, 719-766. http://dx.doi.org/10.1021/acs.chemrev.5b00493

120. Hill, D. E.; Holland, J. P. Comput. Theor. Chem. 2015, 1066, 34-46. http://dx.doi.org/10.1016/j.comptc.2015.05.012

121. Edwards, R.; Wirth, T. J. Labelled Compd. Radiopharm. 2015, 58, 183-187. http://dx.doi.org/10.1002/jlcr.3285

122. Pongratz, E.; Kappe, T. Monatsh. Chem. 1984, 115, 231-242. http://dx.doi.org/10.1007/BF00798414

123. Neilands, O. Zh. Org. Khim. 1965, 1, 1858-1862.

124. Gondo, K.; Kitamura, T. Molecules 2012, 17, 6625-6632. http://dx.doi.org/10.3390/molecules17066625

125. Satyamurthy, N.; Barrio, J. R. WO 2010117435, 2010.

126. Calderwood, S.; Collier, T. L.; Gouverneur, V.; Liang, S. H.; Vasdev, N. J. Fluorine Chem. 2015, 178, 249-253.

http://dx.doi.org/10.1016/j.jfluchem.2015.08.006

127. Rotstein, B. H.; Stephenson, N. A.; Vasdev, N.; Liang, S. H. Nat. Commun. 2014, 5, 4365. http://dx.doi.org/10.1038/ncomms5365

128. Yang, Y.-D.; Azuma, A.; Tokunaga, E.; Yamasaki, M.; Shiro, M.; Shibata, N. J. Am. Chem. Soc. 2013, 135, 8782-8785. http://dx.doi.org/10.1021/ja402455f

129. Arimori, S.; Takada, M.; Shibata, N. Dalton Trans. 2015, 44, 19456-19459. http://dx.doi.org/10.1039/C5DT02214B

130. Huang, Z.; Yang, Y.-D.; Tokunaga, E.; Shibata, N. Asian J. Org. Chem. 2015, 4, 525-527. http://dx.doi.org/10.1002/ajoc.201500067

131. Arimori, S.; Takada, M.; Shibata, N. Org. Lett. 2015, 17, 1063-1065. http://dx.doi.org/10.1021/acs.orglett.5b00057

132. Huang, Z.; Yang, Y.-D.; Tokunaga, E.; Shibata, N. Org. Lett. 2015, 17, 1094-1097. http://dx.doi.org/10.1021/o1503616y

\section{Authors Biographies}




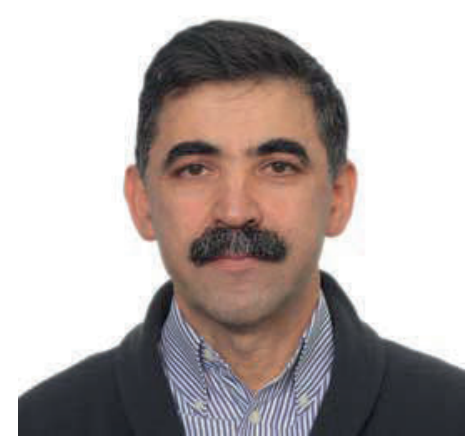

Mekhman S. Yusubov born in Georgia. His M.S. (1985), Ph.D. (1991), and Doctor of Chemical Sciences (1998) degrees were earned at Tomsk Polytechnic University in the laboratory of Professor Victor D. Filimonov. He is a Professor and Department Head at Tomsk Polytechnic University. Since 1994 he has been involved in intense international collaborative research programs with leading research laboratories in South Korea, Germany and United Kingdom. In 2004 he started a joint research in the area of hypervalent iodine chemistry with Professor V. V. Zhdankin at the University of Minnesota Duluth. His main research interests are in the fields of chemistry of natural products and hypervalent iodine reagents. Professor M. S. Yusubov has published over 100 scientific papers.

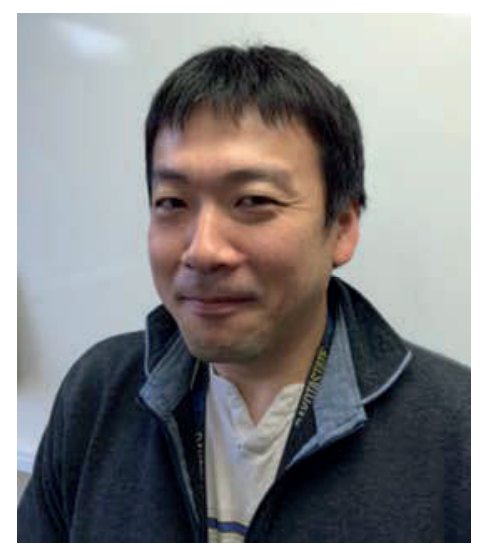

Akira Yoshimura, a native of Osaka, Japan, received his M.S. in 2007 and Ph.D. in 2010, both from Tokushima University, under the supervision of Professor Masahito Ochiai. During 20102014 he carried his postdoctoral work with Professor Viktor Zhdankin at the University of Minnesota Duluth, and in 2015 he was appointed to a Research Associate position in the same university. His research interests are in the fields of synthetic and mechanistic organic chemistry of hypervalent main-group elements and heterocyclic chemistry. He published over 30 research papers, mainly related to the chemistry of hypervalent iodine and bromine. 


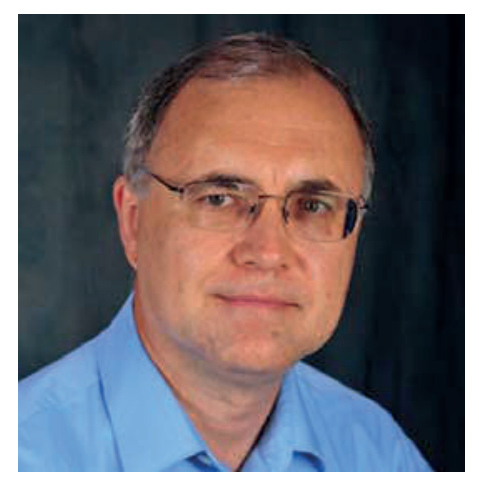

Viktor V. Zhdankin was born in Ekaterinburg, Russian Federation. His M.S. (1978), Ph.D. (1981), and Doctor of Chemical Sciences (1986) degrees were earned at Moscow State University. He moved to the University of Utah in 1990, where he worked for three years as Instructor of organic chemistry and Senior Research Associate with Professor Peter J. Stang. In 1993, he joined the faculty of the University of Minnesota Duluth, where he is currently a Professor of Chemistry. He also has the status of a visiting Professor at Tomsk Polytechnic University. Dr. Zhdankin has published over 250 research papers, gave over a hundred research presentations in many countries, edited several books, co-authored the Handbook of Heterocyclic Chemistry (3rd Edition, 2010) with Professors A. R. Katritzky, C. A. Ramsden, and J. A. Joule, and authored a book on Hypervalent Iodine Chemistry (Wiley, 2013). His main research interests are in the areas of synthetic and mechanistic organic chemistry of hypervalent main-group elements and organofluorine chemistry. In 2011 he received the National Award of the American Chemical Society for Creative Research \& Applications of Iodine Chemistry. Since 2003 he is Scientific Editor and a Member of Control Board of Arkivoc. 